Portland State University

PDXScholar

8-22-1994

\title{
China's policies toward the Soviet Union and the United States before and in the Korean War
}

Ji Bao Yan

Portland State University

Follow this and additional works at: https://pdxscholar.library.pdx.edu/open_access_etds

Part of the Asian History Commons, and the Military History Commons Let us know how access to this document benefits you.

\section{Recommended Citation}

Yan, Ji Bao, "China's policies toward the Soviet Union and the United States before and in the Korean War" (1994). Dissertations and Theses. Paper 3572.

https://doi.org/10.15760/etd.5456

This Thesis is brought to you for free and open access. It has been accepted for inclusion in Dissertations and Theses by an authorized administrator of PDXScholar. Please contact us if we can make this document more accessible: pdxscholar@pdx.edu. 


\section{THESIS APPROVAL}

The abstract and thesis of Ji Bao Yan for the Master of Arts in History were presented August 22, 1994, and accepted by the thesis committee and the department.

COMMITTEE APPROVALS:
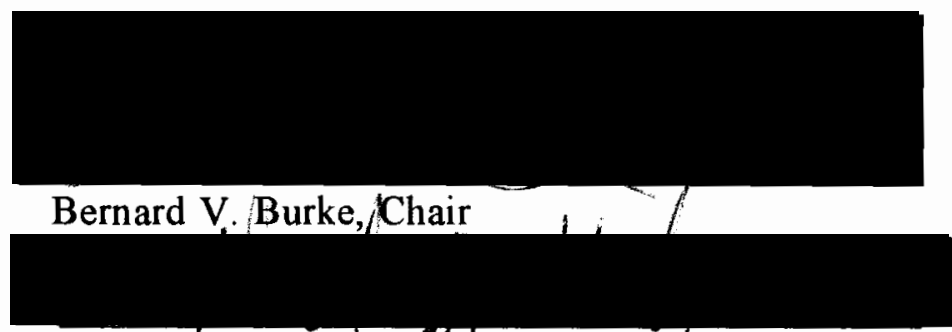

David A. Horowitz

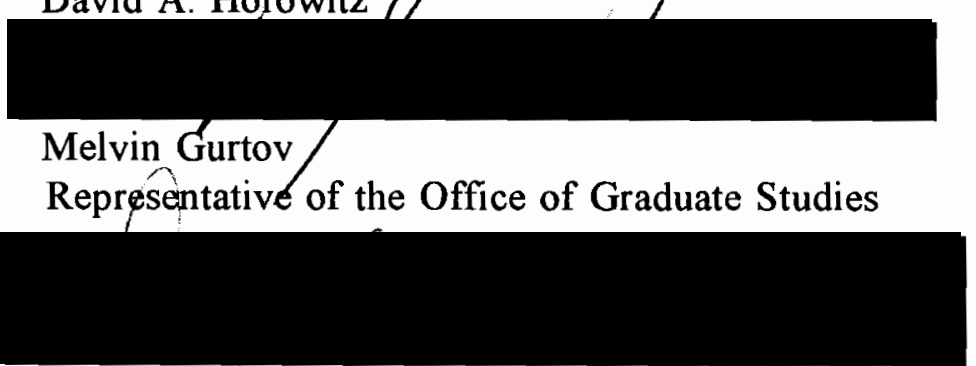

DEPARTMENT APPROVAL:

David A. Johnson, Chair

Department of History

ACCEPTED FOR PORTLAND STATE UNIVERSITY BY THE LIBRARY

by

on

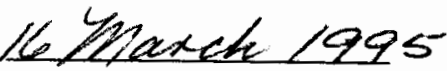




\section{ABSTRACT}

An abstract of the thesis of Ji Bao Yan for the Master of Arts in History presented August 22, 1994

Title: China's Policies Toward The Soviet Union And The United States Before And In The Korean War

In October, 1950, four months after the Korean War broke out, China intervened into the conflict. Facing crucial domestic problems, the strategic goals of the Chinese Communists in both 1950 and 1951 were basically to strengthen the new regime --- to form a solid alliance with the Soviet Union, to capture Taiwan and Tibet, and to recover its collapsed economy. The Korean War totally changed the strategic goals of the CCP.

The reason why China entered into the Korean conflict has been a popular topic among historians. Some historians held that it was for "China's legitimate interests", namely the power supplies on the Yalu border which were vital to Manchurian industry. Now it is believed by most historians that the Chinese leadership's decision for war was based on its security concerns. To help North Korea was equal to defending its own territory. However, the Truman Administration's policy changes towards China in the Korean conflict as well as General MacArthur's aggressiveness mainly contributed to the formation of their intervention decision. 
Miscalculation of situations on the part of the White House policy makers also contributed to the formation of the CCP's intervention decision. They almost surpassed the limit of a "limited war" they had designated.

This thesis deals with China's policy making toward both the Soviet Union and the United States in late 1949 and early 1950 and how they made the decision to enter the conflict, by making use of recently declassified Chinese sources and available American sources.

I agree with most historians that China made the decision to intervene primarily out of security concerns. To be more specific, what the CCP feared was the comingback of Chiang Kai-shek and the loss of their regime. This explains why the CCP have been declaring that they won a total victory over the United States because they saved their communist neighbor from being crashed and they secured their own Manchurian border. 
CHINA'S POLICIES TOWARD THE SOVIET UNION AND

THE UNITED STATES BEFORE AND IN THE KOREAN WAR

b y

JI BAO YAN

A thesis submitted in partial fulfillment of the requirements for the degree of

MASTER OF ARTS

in

HISTORY

Portland State University

1995 


\section{TABLE OF CONTENTS}

CHAPTER

PAGE

INTRODUCTION

1

I COMPREHENSIVE CONTEXT BEFORE THE WAR 3

II THE SINO-SOVIET ALLIANCE 16

III MAJOR CHANGE IN U.S. FAR EAST POLICY AND ITS IMPACT UPON THE KOREAN WAR

IV AFTER INCHON LANDING 56

$\begin{array}{lll}\mathrm{V} & \text { THE FINAL DECISION } & 78\end{array}$

$\begin{array}{ll}\text { CONCLUSION } & 95\end{array}$

$\begin{array}{ll}\text { NOTES } & 97\end{array}$

$\begin{array}{ll}\text { BIBLIOGRAPHY } & 111\end{array}$ 


\section{INTRODUCTION}

In October, 1950, four months after the Korean War broke out, China intervened into the conflict. At this time, the People's Republic of China (hereafter PRC) was only one year old. The Chinese Communist Party (CCP) was still facing crucial domestic problems of how to feed and clothe its five hundred million people, how to consolidate its power, and how to gain as much international recognition as possible. The Chinese Communists were also trying to replace Chiang Kai-shek's Nationalist Government in the United Nations. With its economy and production system in really bad condition, China still aspired to unify its territory by "liberating" Taiwan (Formosa) and Tibet.

In spite of the urgent domestic issues, China confronted the United States in Korea. The reason why China intervened into this conflict has been a popular topic among historians. Some historians hold that it was for "China's legitimate interests" near the frontier ${ }^{1}$, namely the power supplies on the border which Manchurian Industry supplies on the border which Manchurian industry needed. Now it is believed by most historians and scholars(Melvin Gurtov, 1980; Hao Yufang \& Zhai Zhihai; Chen Jian, 1993, etc.) that the Chinese leadership's decision for war was primarily based on its security concerns. To help North Korea was equal to defending its own territory.

By making use of recently declassified Chinese sources, the research achievements of other historians and available American sources, this thesis aims to 
analyze, from a Chinese perspective, (1)the domestic situations of China in late 1949 and early 1950 which confined China to interior goals in early 1950's, (2)the making of the Sino-Soviet Alliance which shows China's eagerness to look for protection, (3)American policy changes toward Communist China before and during the Korean War, namely the dispatch of the Seventh Fleet into the Taiwan Strait and continued assistance of Chiang Kai-shek as well as the crossing of the 38th parallel, obviously offended the CCP leaders and contributed to the formation of their intervention decision, (4)the contacts between the Soviet Union and China, and (5)other factors that led to the decision making of the CCP to enter the conflict, so as to clarify more specifically the motivation and aim of the Chinese intervention. 


\section{CHAPTER I \\ COMPREHENSIVE CONTEXT BEFORE THE WAR}

The People's Republic of China was formally founded on October 1, 1949. It was only about eight months old when the Korean War broke out. China did not get directly involved into the conflict until four months later when the North Korea troops were desperately driven back out of South Korea by the United Nations forces under General Douglas MacArthur. Did China have a positive plan to attack the U.N. forces under any circumstances or did it feel compelled to do so? Did China have the economic potential and resources for a modern war, which requires the total mobilization of civilian production? To address these questions, it is essential to do a comprehensive analysis of China's domestic and diplomatic circumstance in late 1949 and early 1950 .

\section{THE ECONOMY}

The modern history of China was dominated by war. Beginning with the overthrow of the last Chinese emperor in 1911, China experienced wars between the war lords in the 1910s and 1920s; the Northern Expedition Wars of 1926-1927(or the First Chinese Civil War); the War of Land Revolution of 1927-1937(or the Second Chinese Civil War); and the War of Resistance Against Japan of 1937-1949. These wars totally destroyed the economy of China. After years of carnage, by the end of 
1948, Chiang Kai-shek's Kuomintang regime was financially bankrupt. For instance, from June, 1937 to May, 1949, the amount of money in circulation grew 176.8 billion times, and prices rose 250 billion times. The inflation upset the market and gave rise to wild speculation. As a result, the common working people at the payroll suffered and few small or medium business could carry on ${ }^{2}$.

In the summer of 1948, Chiang Kai-shek, under the pressure of both financial problems and unfavorable war efforts against the communists, sent his son, Chiang Ching-kuo to Shanghai to take charge of the Monetary Reform Movement. Chiang Kai-shek gambled on this so-called monetary reform for the recovery of his economy and the seizure of as much gold as possible. In this reform, the Gold Y uan money system was introduced as the sole, legal unit and currency of China, valued at U.S. $\$ 0.25$. It was to be exchanged with the Fabi(the old Chinese currency) at the rate of 1 : 3,000,000. The currency reform finally turned out to be a currency substitution. The common people had no other alternative but to turn in their gold, silver and foreign banknotes for the Gold Yuan notes. The majority of the people were financially ruined during this currency reform campaign. By the end of 1948, the Gold Yuan money became practically worthless. The hyperinflation continued at a faster speed but Chiang Chin-kuo was able to collect about 1.3 million ounces of gold, 34 million U.S. dollars and large amount of other foreign currencies and silver for the Nationalist Government. These gold and foreign currencies were shipped to Taiwan(Formosa) immediately. ${ }^{3}$ Consequently, both the state industry and private business were hurt seriously. ${ }^{4}$ Another factor which hurt China's industry was that at the end of the 
Second World War, the Soviet Union occupied Manchuria briefly and sent back to Russia over half the remaining capital stock there. Statistics shows the industrial base in Manchuria was looted by the Soviet occupation troops of more than two billion dollars worth of machinery and equipment. ${ }^{5}$

According to CIA reports, in 1949 , industry in China only accounted for about $10 \%$ of the gross national output. Production had dropped by $30 \%$ in light industry and $70 \%$ in heavy industry. ${ }^{6}$ Other estimates show that China's industrial production reached its lowest ebb in 1949. Food production was about $25 \%$ below the pre-1949 peak. Consumer goods production was also badly influenced.

When the Chinese Communists took power in October, 1949, they found that the economy left behind by the Kuomintang regime was in "an awful mess" ${ }^{\text {"7 }}$ and their first and foremost task was the feeding and clothing of its millions of people. China's industry was still very backward not only in comparison with Europe and the United States, but also with its close neighbors such as Japan and India. For Instance, the consumption of steel per head in 1950 was (in metric pounds): China, 2; India, 11; and Japan, 111. The output of electricity of China in 1950 was 2,250 million $\underline{\text { KWH }}$ while that of India and Pakistan was 5,63 million $\underline{\mathbf{K W H}}$ and that of Japan was 38,840 million KWH. At the beginning of 1951, the number of spindles in China was only 4 million while there were 10.8 million in India. ${ }^{8}$

In agriculture, the economic situation was equally frustrating. Major crops production in 1949 fell far below the pre-1949 peaks. It was $113,200,000$ tons, $25 \%$ less; the cotton output was 445,000 tons, $48 \%$ less; the output of peanuts was $60 \%$ 
less while draft animals decreased by $16 \%$ and farm implements dropped by $30 \%$. Fertilizers were seldom used on the Chinese farms. ${ }^{9}$

In 1949 , four fifths of the Chinese population were peasants. The density of population, measured by the number of people per unit of cultivated land, was extremely high. The proportion of population engaged in agriculture in China was much larger than in the advanced countries in the West. There was also mass underemployment in the countryside.

In addition to the above problems, there was very little agricultural machinery. In 1951, China had less than 2,000 tractors while the world total amounted to $6,130,000$. In China there were some bare 120,000 acres of arable land per tractor, while it was 20,398 in India. The Chinese peasants had to depend on animals like oxen, horses and donkeys for heavy labor. However, not every farm had animal labor available. Statistics show that less than $50 \%$ of all farms had animals for heavy labor. ${ }^{10}$ Flood and drought also hurt China's economy in 1949 and 1950. There were eight million hectares of farmland inundated by the flood which displaced forty million people. About seven million people were in urgent need of relief. In the cities, about four million workers, handicraftsmen and petite intellectuals were out of job. Many others were only partially employed. ${ }^{11}$

In 1949 and 1950, the transportation system was disorganized to the point of chaos due to decades of international conflicts and civil wars as well as years of neglect. There were about 13,500 miles of railway track, of which less than half was in operation and much of the remainder was in various states of disorganization and 
disrepair. On the other hand, the old railway system before 1949 was mostly designed at the turn of the century by western financial interests and it was little concerned with China's domestic developmental needs. As a result, the system lacked important north-and-south linkages and connections which naturally hampered economic development. ${ }^{12}$ By that time there were under 50,000 miles of main highway in China, of which a little bit more than one third was open to traffic and much of the remainder in an inadequately maintained state. ${ }^{13}$ China had been greatly dependent on inland waterway transportation. But most of the waterway that was open to transportation went from the west to the east except the Grand Canal which starts from Hangzhou and ends at Beijing. Both the Northwest and southwest areas were rich in water resources but were poor in waterway transportation --- commercial transportation could only rely on the underdeveloped railway system and manpower. ${ }^{14}$

By 1949 , foreign trade had fallen very rapidly as the civil war and hyperinflation disrupted the normal channels of communication and trade. Although it recovered fairly quickly, it was still only 1,210 million U.S. dollars. More than one third of this amount was between China and the Communist bloc countries. ${ }^{15}$

Up to 1950 , the rich natural resources of China had not been sufficiently explored. For instance, China was one of the richest countries in coal. Its total known coal reserves were ample to meet the needs of its developing industry. China also possessed the largest known deposits of iron-ore in the world and non-ferrous metals and other minerals such as tungsten, antimony and bauxite. Yet only a small portion of the rich resources were exploited. ${ }^{16}$ 
This backwardness in economy considerably handicapped the people's Liberation Army's strength. In early 1950 , the army of China was one of the most poorly equipped in the world. According to unofficial statistics, a corps in the People's Liberation Army was equipped with about $19070-\mathrm{mm}$ or larger big guns, a limited number of Soviet T-33 and T-34 tanks with no air cover at all, while in one U.S. division there were over $30070-\mathrm{mm}$ or larger big guns, about 140 tanks and most of the units were highly mechanical and mobile with full air cover and navy support. Basically, the three million men of the PLA had only light infantry weapons which they captured from either the Japanese or Chiang's troops. ${ }^{17}$

The above statistics shows that although the CCP had been able to defeat Chiang Kai-shek's troops in the Chinese Civil War and took power in China in a very short period, it did not have necessary economic means and military potential in 1950 to afford a large-scale war against any world power.

Therefore it was natural for the CCP leadership to focus their attention on domestic issues in late 1949 and early 1950. To improve the nation's economic plight, the CCP developed a five-year plan whose goals were:

... to concentrate the nation's main efforts on the construction of the 156 projects designed with the help of the Soviet Union and 694 big and mediumsized industrial projects so as to lay the initial groundwork for socialist industrialization; to foster the growth of agricultural producers' cooperatives, whose system of ownership is partially collective, and handicraft producers' cooperatives so as to lay the initial foundation for the socialist transformation of agriculture and handicrafts; and bring capitalist industry and commerce basically into the orbit of various forms of state capitalism so as lay the groundwork for the socialist transformation of private industry and commerce. ${ }^{18}$

The CCP also demobilized part of it gigantic army and used it for production 
purposes. On December 5, 1949, Mao Zedong issued the order to the Army to participate in production. He wrote,

This production task must be realized because the long years of war unleashed by reactionaries at home and abroad against the Chinese people have brought serious disaster to the people and serious destruction to our economy. Today, we must carry out the revolutionary war to the end, heal the wounds left by the prolonged war, and engage in economic, cultural and national defense construction work. But state revenue is inadequate and expenditures are very great. This is the great difficulty facing us at present. ${ }^{19}$

This order originated from Mao's comprehensive theory for economic development, of which the major steps were, to simplify the governmental organizations; to demobilize part of the army on condition that it maintained enough strength to defend national territory, to liberate Taiwan and Tibet and wipe out the KMT remnants; and to practice strict economy and to raise production. In line with Mao's theory, the CCP's Ordinance Committee put forward the principle of "Munitions production should be combined with civilian needs" as its guideline. ${ }^{20}$ However, as the first Five-year Economic Plan was not activated until 1952, it did not provide any direct help to the Chinese involvement in the Korean conflict.

\section{THE POLITICAL SITUATION}

China was still politically unstable in early 1950. Many intellectuals had doubts about the Communists' ability to run the country. The capitalists were not willing to cooperate with the government. Now and then there was organized KMT sabotage in the newly "liberated areas" such as Southwest and Northwest areas. 
Chiang Kai-shek' regime, by holding Taiwan, had been reorganizing its strength and looking for chances to weaken the new Communist government on the mainland. Zhu De, Commander-in-chief of the PLA, expressed the fear in his statement at a meeting: "The remnants of the Kuomintang gang is now using Taiwan as its base to carry on all kinds of intrigues and plots against the Chinese people. American imperialism continues to help the KMT with arms. The KMT gangsters are using war vessels supplied by America to blockade the China coast; using U.S. aeroplanes to bomb Chinese cities and using American and Japanese military personnel sent by the American occupationists [in Taiwan] to take part in bombing and other military actions."21

It was obvious that Zhu De, basing his charges on false and limited information, exaggerated the danger of American threat and involvement in Chinese affairs. However, his statement was representative of the concern shared by the CCP leaders. Besides, the CCP leaders used this in their propaganda campaign to stir up antiAmerican sentiment as the foundation of their "lean-to-one-side theory".

In order to secure its control of China, the $\mathrm{CCP}$ decided to implement radical measures, including land reforms, industrial transformation from private ownership to state capitalist ownership, political campaigns(political purges) to suppress its political opponents, the Five-year Economic Plan and the preparation to annex Tibet and capture Taiwan. Mao Zedong was determined and aggressive towards the "reactionaries" as he declared: "All the experiences the Chinese people have accumulated through several decades teaches us to enforce the people's democratic 
dictatorship, that is, to deprive the reactionaries of the right to speak and let the people alone have the right."122 Using Mao's theory as the guideline, the CCP launched several political movements nationwide, namely, the Land Reform Movement, the Sanfan Movement(The Movement Against Three Evils 1951-1952), the Wu-fan

Movement(The Movement Against Five Evils 1952), and the Movement To Suppress Counter-revolutionaries (1950-1952).

By early 1950, the CCP deployed the major forces of the Fourth Field Army under Lin Biao along the coast in Fujian province. This move had two purposes: to defend that area and to prepare for the capture of Taiwan. In the meantime, the 18th Corps of the Second Field Army was stationed in southwest Sichuan province bordering Tibet for the preparation of its annexation. The CCP leadership designed the two campaigns as the major task of the PLA in 1950 in the belief that its army, though poorly equipped, was able to wipe out the KMT remnants. This belief was based on the fact that the PLA had wiped out about 8 million KMT troops on mainland China during the Three-year Civil War (CCP statistics) and won a complete victory at Hanan Island by using only wooden vessels and infantry weapons. To the CCP leadership, the Taiwan Campaign and the Tibetan Campaign were the last two campaigns in its efforts to unify the whole country. ${ }^{23}$

\section{THE FOREIGN POLICY}

The foreign policy of the newly-born People's Republic of China was basically built upon two notions: the two-camp(socialist versus capitalist) theory in 
ideology and a nation's political and diplomatic stand towards Taiwan as a dividing line in practice.

Diplomatically, the CCP firmly took the Lean-To-One-Side policy as the CCP regarded China as being a member of the Socialist camp headed by the Soviet Union. Actually the Soviet Union was the first nation to declare diplomatic recognition of the People's Republic of China. Then other Eastern European countries joined the Soviet Union in recognition. In the West, only Great Britain recognized China for consideration of its own commercial interests in Asia(India and Hong Kong) while other major western nations remained pro-Chiang Kai-shek. This made the CCP realize that the chance of their returning to the United Nations was not great. The CCP was also worried about threats from neighboring nations and areas like Japan, South Korea, and Southeast Asian countries since they were all pro-America. As a matter of fact, in Japan, the Philippines, South Korea and Taiwan there were either American troops or military advisors, whose presence in those neighboring areas was regarded by the CCP as composing a major threat to China's security. Primarily out of consideration of its territorial security, the CCP leadership made the decision to ally with the Soviet Union and its Eastern European satellites. This decision excluded any possibility of reconciliation between the United States and Red China. It also committed the CCP to help North Korea when necessary. ${ }^{24}$

In this period, out of the same security concern, the CCP's relations with other countries largely depended upon those countries' attitudes towards Taiwan. This policy found its origin in an old Chinese saying: "My enemy's enemy is my friend; 
My enemy's friend is my enemy." This theory was best explained by a CCP spokesman on April 30, 1949, "Any foreign government which is willing to consider establishing a diplomatic relation with our country should cut off its relations with KMT remnant power, and also withdraw its armed forces from China." ${ }^{25}$ The United States and other major Western countries kept diplomatic relations and economic cooperation with Chiang Kai-shek, they naturally became the CCP's enemy. Mao openly asserted in August, 1949 that "U.S. naval, ground and air forces did participate in the war in China." ${ }^{26}$ For the same reason, Mao later insisted on signing a mutual assistance treaty with Stalin to replace the old one between KMT and the Soviet Union.

Mao Zedong and other CCP leaders were also very much concerned about American military intervention which did not actually exist at that specific time period. How did their perception of this threat evolve? The best answer is perhaps to do with Mao's theory of the "intermediate zone' which found its basis in his understanding of the Cold War worldwide.

Mao's argument was that even though the United States and the Soviet Union were confronting and competing each other, they were separated and protected by a vast zone that consisted of many capitalist, colonial and semi-colonial countries in Europe, Asia and Africa. Mao asserted that the capitalist bloc would take other socialist countries before they eventually attack the Soviet Union simply because of the geographical buffer of this vast zone.

To the CCP leaders, Mao's intermediate theory made sense. The CCP leadership 
strongly believed that the United States was leading a conspiracy to encircle China by means of the Truman Doctrine, the Marshall plan, the recovery and reformation of both Germany and Japan, American occupation South Korea, and particularly, American military assistance to Jiang Kai-shek's regime on Formosa as well as the stationing of American marines along China's coast.

The CCP's distrust of America's China policy found its roots in the few occassions when the CCP had contacts with the Americans. They felt that they were cheated and humiliated by the Americans. It was true especially during the three years of the Third Chinese Civil War(1946-1949) when the Americans were openly mediating between the CCP and Jiang Kai-shek and indirectly assisting the latter(in terms of money, munitions and advisors).

Mao bitterly believed that the Americans were one step short of declaring war upon the Chinese Communists. Mao also believed that the fact that the United States did not get directly involved in the Chinese Civil War was not because they lacked the intention to do so but because the overall situation of the world forbade them from doing so. This laid the basis of the CCP's long-term hostility towards the United States. However, it did not mean that the CCP was heading toward a large war with the United States.

Generally speaking, rather than preparing for war, China was preoccupied with measures to stabilize its economy and strengthen its national defense by allying with the Soviet Union and unifying its territory in early 1950 although they were very hostile to the United States and had adopted the Lean-To-One-Side policy 
diplomatically. To involve in a general war was quite out of the agenda of the CCP and was something it could hardly afford. China later entered the Korean War when the CCP leadership felt its territory was under threat and felt absolutely necessary to do so. 


\section{CHAPTER II \\ THE SINO-SOVIET ALLIANCE}

The Sino-Soviet Mutual Assistance and Friendship Pact which was signed in February, 1950 was a milestone not only in the relationship between China and the Soviet Union, but also in the Cold War. It was actually a military pact which tied China with the Soviet Union, marked the beginning of the Cold War in Asia, and greatly influenced the strategic order in the Far East during the 1950s and 1960s. Why did the CCP decide to ally with the Soviet Union? How did it affect the situation in Asia? Was it decisive to the outbreak of the Korean War? This chapter seeks to answer questions in terms of the origins of the Sino-Soviet Alliance both practically and ideologically as well as its influence upon the Korean conflict.

Even before it took power nationwide in China, the $\mathrm{CCP}$ realized that it must lean to one side, to ally with one of the powers in the world for the protection of Chinese interests and the leadership in Asian affairs. This theory was based on the Chinese Communist leaders' conviction that the majority of western powers were capitalist countries and they were doomed to perish while China was a newly-born socialist country and there was nothing in common between China and western powers. The CCP leadership felt that China should play a special and leading role in Asian affairs. But Red China's status rested only on its size, population and geographical position, not on its military or economic strength. Like China under Sun Yat-sen and Chiang Kai-shek, Mao's China had to ally with a world power to build up its status in Asia. 
Although nationalism has been a driving force behind the CCP actions and policies, the ideological convictions of the CCP definitely shaped their view of the world, molded their strategy and provided the rationale for the means of their policy. Mao once said, "In the end, the socialist system will replace the capitalist system. This is an objective law independent of human will. No matter how hard the reactionaries try to prevent the advance of the wheel of history, revolution will take place sooner or later and will surely triumph. ${ }^{27}$ Among the world powers around 1949, the Soviet Union was the only appropriate ally. First of all the Soviet Union was a socialist country under Stalin's dictatorship while China was going to be a socialist country under Mao's dictatorship. Secondly, the Soviet military power was one of the strongest in the world. Thirdly, the Soviet Union's geographical position as China's close neighbor made it possible to provide instant assistance when necessary.

Nevertheless, Mao had some problems with Stalin in the 1930s and 1940s concerning the Third Communist International. In the Second Chinese Civil War(1927-1937), Stalin sent Wang Ming and Po Ku back to China to direct the Chinese revolution there. They were resisted by Mao's local Communist principles. They were eventually rejected from the CCP leadership as they firmly followed Stalin's directions. Mao called them rigid Marxists, blaming them for failing to combine the Communist classics with the actual development of communism in China. This could be seen especially in the Second Chinese Civil War(1927-1937). Wang Ming and other Soviet-oriented CCP leaders insisted on regular military confrontation against the regular well-equipped KMT army --- (To Keep the enemy outside the 
Gate) while Mao suggested irregular mobile guerrilla warfare, laying emphasis on wiping out the major forces of the KMT troops. In the Fifth Anti-encirclement Campaign the Red Army adopted Wang Ming's strategy. As a result the Red Army failed to smash the encirclement and had to move from south China to the north. When the major force of the Red Army reached Shanxi, they lost 90 per cent of their men and most of their bases in the south. The lesson was serious and paid with blood.

During the War of Resistance Against Japan Mao cautiously allied his fairly weak Red Army first with Chiang Kai-shek, then with the Soviet Union and the United States under the name of the United Front Against the Aggressors. This strategy proved to be successful in retaining the strength of Mao's forces as well as its development. By the end of the War, Mao's forces expanded to about one million in manpower plus more than two million militiamen.

During the Third Chinese Civil War(1946-1949) Mao's forces fought the war out almost single-handed --- Soviet military assistance was very limited ---- they did not get any substantial military assistance from the Soviet Union because at the Yalta Conference Stalin promised Franklin Roosevelt that he would never aid the CCP in the internal conflict of China in exchange for American recognition of Outer Mongolia and other concessions in China. The CCP was obviously unhappy about this, which resulted in inharmonious relations between Stalin and Mao. Mao complained: "It is also entirely possible that he wanted China to remain divided for a long period...."28 On the other hand the Soviet leaders generally doubted the CCP's ability to win the war against Chiang Kai-shek. Therefore the Soviet Union took a neutral position in 
the Third Chinese Civil War while Chiang Kai-shek clearly followed a pro-American policy. ${ }^{29}$

Actually, during the Third Chinese Civil War, there was full Soviet diplomatic support for Chiang Kai-shek on the basis of the Nationalist-Soviet Treaty and no recognition of Mao. Stalin's personal comments on Mao's Communist movement in China were not very positive. Stalin told the U.S. Ambassador in June, 1944: "The Chinese Communists are not real Communists. They are margarine Communists". He also called them "cabbage" Communists and "radish" Communists. ${ }^{30}$ Stalin repeatedly affirmed to the West that he only recognized Chiang's Nationalist Government. He promised in May, 1945 that he would do everything he could to promote unification of China under the leadership of Chiang Kai-shek. At Potsdam, Stalin openly declared that "Chiang Kai-shek's Government was the only possible government in China and that the Chinese Communists were not real Communists at all." ${ }^{31}$ Lacking respect for CCP leadership, Stalin repeatedly interfered in their affairs --- he appointed through the Third Communist International the leaders of the Chinese Communists Party, namely Qu Qiubai, Li Lisan, Wang Ming, Po Ku and Zhang Wentian. Mao Zedong was not one of the Stalin's appointees. When Mao seized the power within the CCP, Stalin actually knew little about him, which affected the relationship between the two parties to a certain extent.

As a result the military equipment of the PLA in the civil war was actually what they could capture from the Japanese and Chiang's troops. The former U.S. Ambassador to Chiang's regime J. Leighton Stuart said in October, 1947 that there was 
"little if any evidence of material assistance from Moscow" to the Chinese Communists. ${ }^{32}$ Actually when the Second World War was over, Stalin was much less concerned about the development of the situation in China than about his own safety and fear of violating the spheres of influence prescribed at the Yalta Conference. It was not until Mao's troops reached the Yangtze River in early 1949 that Stalin sent his special envoy Anastas Mikoyan to Mao's headquarters in Sibaipo, Hebei province of China, to get in contact with Mao for first-hand information concerning the Chinese Revolution. The envoy brought Stalin's advice that CCP had better not cross the Yangtze River to avert triggering a direct Soviet-American confrontation. Mao and the CCP did not listen to Stalin. Mao told Mikoyan that it was only a matter of time for the CCP to win national victory. Mao pointed out that it was necessary for the PLA to go across the Yangtze River to wipe out the remnants of the KMT troops so as to "carry the revolution through to the end." Zhou Enlai explained to Mikoyan the CCP's plans to construct the political system and the economy as well as the framework of China's diplomatic relations. Although Mikoyan's visit did not result in direct large-scale Soviet assistance to the $\mathrm{CCP}$, its significance was far-reaching as it was the first formal contact between the CCP leadership and the Kremlin leaders. ${ }^{33}$ When the CCP won the three decisive battles against the KMT, they immediately went across the Yangtze River in April, 1949 and captured Nanking, Chiang's capital. Even after the capture of Nanking, the Soviet ambassador to Chiang's regime left with Chiang's central government to Canton(Guangzhou). This embarrassed the CCP and made it difficult to establish close strategic cooperation between the CCP and the 
Soviet Union. ${ }^{34}$

However, China and the Soviet Union had one thing in common --- they were both Communist countries in essence which eventually led to a close cooperation between them later. When the People's Liberation Army was driving Chiang Kai-shek out of the mainland to Taiwan, both Stalin and Mao saw the necessity to become allies for each other's interests and established more friendly relations. The CCP tried its best to embrace the then current Soviet picture of a world sharply divided into only two hostile camps -.-- the socialist and the capitalist. Liu Shaoqi, the vice CCP chairman, wrote, "The world today has been divided into two mutually antagonistic camps: on the one hand, the world imperialist camp, composed of American imperialists and their accomplices, the reactionaries of all countries of the world; on the other hand, the world anti-imperialist camp, composed of the Soviet Union and the New Democracies of Eastern Europe, and the nationalist liberation movements in China, Southeast Asia and Greece, plus the people's democratic forces of all countries of the world. American imperialism has become the bastion of all the reactionary forces in the world; while the Soviet Union has become the bastion of all progressive forces...." ${ }^{35}$ This analysis served as the guideline for the CCP for about 25 years until 1974 when Deng Xiaoping put forward the Three-World theory at the United Nations.

In the formation of the alliance between the CCP and the Soviet Union, there were two remarkable events. One was the visit of Liu Shaoqi to Moscow; the other was the visit by Mao Zedong himself to Moscow. Liu's visit paved the way for the normalization while Mao's visit built up the military alliance between the two 
communist giants and marked the beginning of confrontation between the East and the West in East Asia.

Liu Shaoqi visited Moscow in July, 1949. Liu was authorized to discuss with Stalin all the important issues concerning the international situation and Chinese-Soviet relations. Mao and other CCP leaders were very much concerned with this visit. He issued the famous "Lean-To-One-Side" policy just two days before the delegation headed by Liu Shaoqi departed for Moscow. The timing was purposely set. The implied message in the issue of the Lean-To-One-Side policy was very clear: China would not be another Yugoslavia and it was ready to cooperate with Stalin.

At a private meeting with the Chinese delegation Stalin apologized for his failure to render sufficient support to the $\mathrm{CCP}$ in the Third Chinese Civil War: "...we have been in the way of hinderance to you because our knowledge about you is too limited." ${ }^{36}$ This was really a surprise to Liu and other Chinese present. This apology served as a clear sign that Stalin had realized the importance of the CCP in Asian affairs and was willing to treat the $\mathrm{CCP}$ as equals. Equal treatment was just what Mao wanted from the Soviet Union.

Then Liu discussed with Stalin Soviet support of the newly founded People's Republic of China, especially the recognition of the republic which was the major issue of the CCP. It was obvious that the Western countries would not recognize China soon. On the other hand the recognition by the Soviet and other Communist countries in Eastern Europe was vital to the existence of China and it had not been guaranteed. Stalin's response was very positive. He promised to support China 
unconditionally, which greatly encouraged the CCP leadership. It decided to speed up the formation of the Chinese central government and try to shorten the major difference between the CCP and the Soviet leadership.

Liu also discussed with Stalin settlement of the border problems concerning China's Sinkiang(Xinjiang) Province where the Russians once had a great influence and the Soviet Union had never openly given up its claims in the region. Stalin once helped to set up communications between the CCP agents working in Sinkiang and the CCP headquarters and used the revolutionary forces in Sinkiang supported with his arms to check the KMT forces there.

Lastly Liu and Stalin discussed the issue of responsibilities of both the Soviet Union and Red China in Asia and in the world. Stalin expressed his hope that China should play a more important role in Asian affairs. That is to say, the Soviet Union would pay more attention to the west, especially Europe since Stalin was mostly concerned about a possible invasion from Central Europe, while China should take care of East Asian affairs as China had a great influence upon colonial and semicolonial countries in the East. ${ }^{37}$ Liu's meeting with Stalin resulted in a consensus that the Soviet Union was going to remain the center of world revolution and China was going to promote the revolutionary movements in Asia. ${ }^{38}$ It is very likely that Liu also discussed with Stalin the issue of Korea but so far no direct Chinese sources could prove this. Coincidentally, two divisions composed of Korean soldiers of the PLA Fourth Field Army --- 164th and 166th divisions --- were sent back to Korea with their equipment just around the time of Liu's visit in Moscow. Therefore we have a reason 
to believe that it had something to do with Liu's visit or Liu might have talked with Stalin about the unification of Korea. ${ }^{39}$

Then Mao sent directions to Liu for further cooperation with the Soviet Union in August. Liu signed an agreement with the Soviet Union for Chines-Soviet cooperation in establishing China's air forces. As a result China received a total of 185 planes of different types from the Soviet Union by the end of 1949. In September, 1949, another Chinese delegation headed by General Zhang Ai-ping visited Moscow and made an agreement for Soviet assistance on China's navy. By the end of the year there were 90 Soviet Naval experts working with the Chinese navy. Liu's visit to Moscow substantially paved the way for the normalization of relations between the CCP and the Soviet Union. ${ }^{40}$

The Soviet Union was the first nation in the world to recognize the People's Republic of China. It did so on the second day of PRC's founding. The Soviet government informed Zhou Enlai that it would establish diplomatic relations with the PRC and end all relations with Chiang's regime. Accordingly, the CCP decided to establish diplomatic relation with all new communist countries as soon as possible. Now the CCP realized that it was the time for Mao to visit Moscow personally for an alliance with the Soviet Union and they started to prepare for such a visit immediately.

Mao's goal for this visit was very clear --- he was trying to sign a mutual assistance treaty with Stalin to replace that between Chiang's regime and the Soviet Union. The significance of this visit lies in what Mao said at the time: "This would place the People's Republic in a favorable position by forcing those capitalist countries 
to fit themselves to our principles.; Foreign countries would be forced to recognize China unconditionally as well as to abolish those old treaties and sign new treaties with us; and those capitalist countries would dare not to take rash actions against us." ${ }^{41}$

One remarkable feature of Mao's visit to Moscow was the length of his stay --Mao left Beijing on December 6, 1949 for Moscow and stayed there until midFebruary, 1950. More than two months' stay for a head of state on an official visit in a foreign country was unusual and quite unprecedented. Besides this was the first visit Mao made in his life to a foreign country. The answer to all this can be found in Mao's own words when he was answering Stalin's greetings: "For this trip we hope to bring about something that not only looks nice but also tastes delicious." ${ }^{42}$ This meant something substantial: a new alliance between the two communist countries.

This was also the first time Stalin and Mao met each other. Both were cautious and polite. Stalin praised Mao highly: "Great! Great! You have made tremendous contributions to the Chinese people. You are their good son. I wish you good health." ${ }^{43}$ Then Mao frankly told Stalin of the grievances he felt during the early years of the Chinese Communist Party. This unusual act surprised every Chinese present because nobody knew Mao would put forward such an issue at the first meeting with Stalin. Probably Mao wanted to tell Stalin that he was wronged by the pro-Soviet Bolsheviks sent to China by Stalin and he was a person who would not have any problem with the Soviet Union. Stalin consoled Mao by saying: "Now you are a winner, and a winner should not be criticized." ${ }^{14}$ Then Stalin expressed his wish to develop a new relationship with Red China. 
Nevertheless, it was not an easy job for Mao to sign a treaty with Stalin. At first Stalin hesitated for a while, basically for two reasons: 1) Stalin got reports about the CCP policies and problems from I.V. Kovalev, the chief Soviet advisor to China. Kovalev reported that some former anti-Soviet CCP members headed by Liu Shaoqi were then organizing some groundless criticism against a pro-Soviet CCP V.I.P. Gao Gang who was a senior Politburo member of the CCP and the chairman of government in the Northeast region(Manchuria). This report made Stalin's attitude towards Mao dubious; 2) Stalin was concerned over a possible violation of the spheres of influence agreed upon at the Yalta conference --- an over-intimate relationship between China and the Soviet Union might cause great concern in the United States which could make Asia become a hot spot of the Cold War. ${ }^{45}$

Through Wang Jiaxiang, the Chinese Ambassador to the Soviet Union, Mao expressed his wish to abolish the old Sino-Soviet treaty of 1945 between Chiang's regime and the Soviet Union. Stalin finally agreed to sign a mutual assistance and friendship treaty with Mao as he realized it was better to ally with Mao than to continue Soviet relations with Chiang. In the meanwhile he was worried that China might also follow the road of Yugoslavia and become independent from him.

The Chinese side put much thought in the drafting of the treaty document in order to guarantee protection from the Soviet Union. Mao did not take part in the negotiations concerning the treaty. Zhou Enlai as the foreign Minister talked with Andrei Vyshinsky, the Soviet Foreign Minister, for details of the treaty. The draft of the treaty was worked out by the Soviet side. The Chinese side deliberated and 
revised the draft version of the treaty item by item, sentence by sentence. Zhou was extremely serious and cautious in considering every single word. Zhou's idea was that "The treaty should be all right not only now but also in the future, and it should be able to pass the test of time and examination by posterity." ${ }^{46}$ The veteran Chinese diplomat $\mathrm{Wu}$ Xiuquan who accompanied Mao and Zhou to Moscow recalled that the treaty was condensed into a text of under 1,000 words but every word had been repeatedly considered. For example, one of the clauses read: "In the event that one of the contracting parties was invaded by a third state, the other contracting party shall render assistance." ${ }^{47}$ Zhou felt this was not firm enough and that it did not truly reflect the effectiveness of the treaty. Zhou added after "shall render assistance" the phrase "by all the means at its disposal." The whole sentence would read as "In the event of one of the High Contracting Parties being attacked by Japan or states allied with it, and thus being involved in a state of war, the other High Contracting Party will immediately render military and other assistance with all the means at its disposal." ${ }^{48}$ This sounds more affirmative and clear-cut. Because of Stalin's concern, this phrase was later discussed and disputed for quite some time but it was finally accepted by the Soviet side.

It was not until February 14, 1950 that the "Treaty of Friendship, Alliance and Mutual Assistance Between the PRC and the Soviet Union" was finally signed, which was accompanied by a grand signing ceremony in the Kremlin. The meaning of this treaty lay in the speech Zhou Enlai made at the celebration ceremony: "The significance of the treaty and agreements between China and the Soviet Union is of 
particular importance for the revived People's Republic of China. This treaty and these agreements will help the Chinese people to realize that they are not alone, and will help in the restoration and development of Chinese economy." ${ }^{49}$ But the speech made by A.Y. Vyshinsky was quite different as it laid emphasis on friendship and mutual interests instead of the alliance: "The Treaty.... expresses the striving of both our peoples for eternal friendship and co-operation for the good of our countries, for the strengthening of peace and the security of the nations." ${ }^{50}$ This difference shows that the Soviet Union and China were not totally agreed on some issues ---- The Soviet side was not happy about the way the CCP treated Gao Gang, a pro-Soviet CCP leader; Stalin and Mao had different ideas about the way to sign the treaty (Stalin thought it better to be signed by himself and Mao while Mao insisted that it had better be signed by the premiers of both countries since this was something between the two states and would sound more formal); and the Soviet Union was hesitant to make a clear military commitment to China(in the form of a military alliance which might touch the nerves of the West as Stalin worried). ${ }^{51}$ In 1962, Mao recalled the problems concerning the signing of the Treaty as he noted:"...Later when I went to Moscow to sign the Sino-Soviet Treaty of Alliance and Mutual Assistance, we had to go through another struggle. He was not willing to sign a treaty. After two months of negotiations he at last signed. When did Stalin begin to have confidence in us? It was at the time of the Resist America, Aid Korea Campaign, from the winter of 1950. He then came to believe that we were not Tito, not Yugoslavia." ${ }^{52}$

At the same time the Agreement on Chinese Changchun Railway, Lushun(Port 
Arthur) and Dalian(Dairen) Between China and the Soviet Union was signed as the Changchun Railway had been an issue that caused troubles between China and the Soviet Union. Three days later on February 17, 1950, Mao and Zhou Enlai went back to China, the goal of reasonably guaranteed protection from the Soviet Union having been achieved.

To China the Treaty was more symbolic than substantial in terms of economic assistance from the Soviet Union --- the Soviet Government agreed to grant long-term credits amounting to $300,000,000$ American dollars at one per cent interest over a period of five years for the purchase of industrial equipment from the Soviet Union unlike Soviet aid to East European countries which did not charge any interest. This amount was far less than what China needed for the recovery of its economy. China probably could have gotten more credits from the Western countries if it had realized normal relations with the western countries. ${ }^{53}$

In commenting on the Sino-Soviet Treaty, historian Wang Gungwu thought that the Chinese decision to side with the U.S.S.R. was "fateful" as "it had serious repercussions for the P.R.C. in the United Nations, in the U.S. intervention in Korea and the Taiwan Straits, and in the Cold War... But it also had a positive impact on China's internal development.... What was crucial, however, was the confidence that the Soviet backing gave to China's sense of security and sovereignty and the way this enabled the Chinese to concentrate on the immense task of national reconstruction." ${ }^{54}$

Another feature of Mao's visit in Moscow was its impact upon the coming Korean conflict. The fact was that Kim Il Sung, the North Korean leader also visited Moscow 
around the time of Mao's visit. It was not a coincidence. Kim Il Sung deliberately planned this visit. ${ }^{55}$ With very clear purposes, he was seeking military assistance by every effort from both the Soviet Union and China for launching a war upon South Korea while Mao was staying in Moscow. Kim Il Sung optimistically thought that the time was ripe for North Korea to "liberate" the south because in South Korea there were rich resources of rice plantation lands, fine weather for crops, advanced fishery which could provide the north with food for its people and the north could provide the south with raw materials for its industry; the North Korean Communist Party organizations were all over the South and did much political propaganda work. So long as the Central Committee gave the order, the people in the South would rise in arms to overthrow the South Korean Government; and the North Korean army was superior to the South Korean army. If they were going to launch a surprise attack, Kim was sure that he could win the war. ${ }^{56}$

Stalin had some concern that the United States might interfere. This was the reason why Stalin withdrew the Soviet military advisors from North Korea when the United States strongly criticized the North Korean aggression. Stalin's idea was "If we leave our advisors there, they might be captured which would be used by the United States as an excuse to interfere. This was something Kim II Sung has got to take care of by himself." 57

On the other hand, Mao's response was definite. He agreed to Kim's proposal to launch the attack upon the South, believing that the United States would not interfere as this war was going to be only an internal affair among the Koreans themselves ---- 
other nations had no right to interfere. Mao also promised to send in his ground forces only when necessary. At the same time Stalin agreed to provide air cover for the Chinese ground forces. ${ }^{58}$

Mao's optimistic opinion about the Korean situation seemed to be contradictory to his hesitation later on when the CCP was going to intervene in the Korean conflict. Obviously what Mao said in Moscow was based on his miscalculation of the situation as he had not expected the United States to react so promptly. Both Mao and Kim Il Sung figured that North Korea could easily unify the Korean peninsula before the United States and other Western countries could do anything. On the other hand, Mao did not expect that China had to enter the war directly. He was speaking more from the angle of an onlooker, which led him to dwell on communist internationalism, than a direct participant of the conflict.

The former Soviet Chairman, Nikita Khrushchev, recalled that he had the same idea as Mao that this was a national liberation war instead of a war of one nation against another. Khrushchev admitted that by the time when the three Communist leaders met in Moscow the Soviet Union had already provided much arms to North Korea, including tanks, big guns, rifles and munitions. ${ }^{59}$

In January, 1950, Mao also promised to send back to Korea more Korean soldiers serving in the PLA with their weapons and equipment as a substantial support for the coming Korean Conflict. By the fall of 1950 , more than 100,000 North Koreans were returned to North Korea. ${ }^{60}$

It is possible that the Soviet Union, China and North Korea formed a sort of 
Communist triangle alliance in early 1950 and reached agreement on the issue of sponsoring a North Korean attack upon the South. Nevertheless, it does not mean that China would play an active role or be directly involved at the very start of the Korean War as it did not have the necessary military potential and economic resources to do so. On the other hand China was preoccupied with its domestic affairs in late 1949 and early 1950, such as the capture of Taiwan, the annexation of Tibet and the recovery of its economy. China later entered the Korean Conflict basically out of its own security concern, that is, the protection of its own interests and its power. 


\section{CHAPTER III \\ MAJOR CHANGES IN U.S. FAR EAST POLICY AND ITS IMPACT UPON THE KOREAN WAR}

When the Second World War was over, both the communist leaders and western leaders began to realize that the major confrontation in this world was going to be that between the East and the West. While the Soviet Union was tightening its control over East European countries, the western powers became alert about the ambitious expansion of the Soviet Union.

In January, 1946, the United States Joint War Plans Committee projected that instead of seeking buffer zones along its borders, the Soviet Union aimed to dominate the "Eurasian landmass"and all of its approaches. This implied that the Soviet Union wanted nothing less than world domination and the destruction of capitalism. In February, the War Department advised President Truman that the United States should not compromise on principle and should provide bilateral support to nations threatened by Soviet expansion. In order to meet the perceived threat the Joint Chiefs of Staff desired a policy with global responsibility ${ }^{61}$

On March 5, 1946 Sir Winston Churchill made his famous Fulton speech in Harry Truman's home state, Missouri. His message was clear that the untrustworthy Soviet Union was not going to be civilized and he called upon "the fraternal association of English-speaking peoples"62 to prevent war and further Soviet expansion. Churchill's remark impressed most Americans that it was time to stop communist expansion. In 
February, 1947, while trying to solve the problems in Turkey and Greece, Truman made a statement of policy known as the Truman Doctrine: that the United States should support free peoples who are resisting attempted subjugation. The president then requested $\$ 400$ million in economic and military assistance. His new policy won majorities in both houses. It meant clearly that Russia must be stopped, contained within her own territory; the United States at last had believed that the Soviet Union was bent on world revolution which was going to be a greater menace to freedom than Nazi Germany. The Cold War was triggered.

In the following two years, the United States and the West underwent tests on issues of the Marshall Plan for the recovery of Europe, Point four Program, the Berlin blockade, Rival Governments in Germany, NATO and Warsaw Pact and the rise of Red China. Those issues contributed to the elevation of confrontation between the East and the West.

Between late 1949 and early 1950, U.S. policy in the Far East changed considerably. These changes not only had a great influence on later Sino-American relations, but also directly had some impact upon the coming conflict in Korea.

On July 1, 1949, when the Chinese Nationalist Government asked the United States for help again, Dean Acheson responded that "the United States stands ready to help, but first China would have to give evidence of ability to help herself." ${ }^{63}$ This was a signal that the United States would soon abandon the thought of involvement in China since it had been so costly. On the other hand, Acheson still hoped that "the United States might have the capability to prevent the further expansion of 
Communism on the Asian continent and into Southeast Asia." ${ }^{64}$

On August 5, 1949, the State Department published the Clina White Paper. This document served mainly as a summary of United States' China policy since the end of the Second world War. It also aimed to shift America's responsibility for losing the war (the Third Chinese Civil War between Chiang Kai-shek and Mao Tse-tung's Communists, 1946-1949), trying to place all the blame upon the Chinese Nationalist Government itself -- the United States policy had been in no way responsible for the "ominous result". It implied that the support of the Nationalist Government and the efforts of the United States toward survival of the government were at an end. ${ }^{65}$

The CCP did not give any credit to the United States for its attempt to abandon Chiang Kai-shek. Following the release of the China White Paper, Mao Zedong published two important articles, Cast Away Illusions, Prepare for Struggle, and Farewell, Leighton Stuart. Mao stated that the China White Paper "reflects the victory of the Chinese people and the defeat of imperialism." ${ }^{66}$ While regarding this as a good opportunity to speed up their conquest of the whole country, Mao warned his party members not to forget the possibility of U.S. direct military intervention and "Prepare for struggle". ${ }^{67}$ Mao's argument was that the United States would sooner or later come back, his theory being that "by seizing China, the United States would possess all of Asia." ${ }^{68}$

Both Harry Truman and Dean Acheson, seeing that there was nothing they could do to prevent the collapse of the Chiang kai-shek regime, made the decision to cease financial assistance to Chiang. Actually, Chiang's regime was too inefficient and too 
corrupt, which certainly led Truman to declare that "We are not going to give the Chinese a nickel for any purpose whatever" because "all the money we have given them is now invested in United States real estate. ${ }^{69}$ Besides, the President had realized that "Peace in the world would not be achieved by fighting more wars" and that "there were two enormous land masses that no western army of modern times had ever been able to conquer: Russia and China. It would have been folly, and it would be folly today, to attempt to impose our way of life on these huge areas by force."

When Chiang's regime was retreating from mainland China to Taiwan(Formosa), the attitude of the State Department was resolute: "Any overt military commitment in Formosa would be unwise at this time as the establishment of U.S. military forces on Formosa in the present situation would be not only diplomatically disadvantageous but also, and far more important, a heavy political liability for us." ${ }^{71}$ Political and economic measures were suggested to help stop the advance of communism toward Taiwan and southeast Asia. It was also suggested that units of the United States Navy had better not be stationed at or off Formosan ports in support of the political and economic measures because if the United States was going too far in the involvement of the case of Formosa, it would be utilized by the Communists to arouse anti-U.S. sentiment. ${ }^{72}$

Due to the inefficiency of the Chiang Kai-shek's government and the nonassistance policy of the United States, the People's Liberation Army(PLA) under the Chinese Communists was able to capture the mainland of China in a short period.

Based on the above-mentioned issues, the White House set up its global defense 
strategy --- Global communist expansion must be deterred with the major theater in Europe; China was gone due to the inefficiency of Chiang's corrupted government -better leave the door open for possible entente with the new regime in the future. These two principles can be seen in coming measures taken by the Truman Administration.

First, President Harry Truman declared on January 5, 1950 that "the United States had always stood for good faith in international relations. Traditional United States policy toward China, as exemplified in the Open-door policy, called for international respect for the territorial integrity of China... The United States has no predatory designs on Formosa or on any other Chinese territory. The United States had no desire to obtain special rights or privileges or to establish military bases on Formosa at this time. Nor does it have any intention of utilizing its armed forces to interfere in the present situation. The United States Government will not pursue a course which will lead to involvement in the civil conflict in China." ${ }^{73}$ The ambiguous language of this statement could be interpreted in various ways. A possible communist understanding of this could be that the United States would not interfere or render any further military assistance to Chiang Kai-shek if the PLA was going to capture Formosa and other places remaining under Chiang's control although the real intention of the United States was to "develop and support a local non-communist Chinese regime which will provide at least a modicum of decent government for the islands." ${ }^{74}$ In addition to the President's statement, Dean Acheson stated at the 35th Meeting of the National Security Council on the Formosa problem, "We must carefully conceal 
our wish to separate the island from mainland control." Then he acknowledged that "our feeling is that, given the tactics employed by the Communists in seizing power, the use of our military power, short of complete blockade and occupation, will be inefficient to prevent Communist control of Formosa" and that "We are under no illusions that we can through present diplomatic and economic measures guarantee a denial of Formosa to the Communists. ${ }^{175}$

The president and the secretary of state looked at this matter from a practical viewpoint: "We maintain diplomatic relations with other countries primarily because we are all on the same planet and must do business with each other. ${ }^{76}$ But this was far from an intention to develop official diplomatic relations with Communist China soon.

In the Memorandum by Gerald Stryler of the office of Chinese Affairs, it was suggested that "Nothing is to be lost by recognition, nothing to be gained by nonrecognition; non-recognition would hamper trade or make trade impossible; Chinese public opinion will be more favorable to the U.S. if the U.S. recognizes; recognition might make possible reestablishment of the tradition U.S. policy of the Open Door; and only by recognition can relations with the Chinese be 'normalized."'77 Stryler further suggested that the United States should begin at once to disentangle itself from the Nationalist Government. ${ }^{78}$

In his personal letter to the president, Dean Acheson explained the United States interests in China and the importance to maintain relations with Mainland China by dating back to the "religious, philanthropic and cultural ties which have united the two 
peoples" and "the use of the Boxers' indemnity for the education of Chinese students, the abolition of extraterritoriality during the Second World War and U.S. extensive aid to China during and since the close of the war." ${ }^{19}$ Acheson seemed to be in favor of setting up normal relations with mainland China.

Soon, the Truman Administration made another dramatic move in its Far East policy, which had some effect on later events in the Far East. On January 12, 1950, Dean Acheson presented a statement of policy before the National Press Club for the purpose of discussion of American policies in the Far East. In commenting on the viewpoint that the real interest of the United States was to stop the spread of communism, Acheson described it as "put the cart before the horse" as he said that "of course we are interested in stopping the spread of communism. But we are interested for a far deeper reason than any conflict between the Soviet Union and the United States." ${ }^{180}$

Based on the same ground, the outline of Dean Acheson's national security perimeter of the United States was presented in the following way: "This defensive perimeter runs along the Aleutians to Japan and then to the Philippines Islands." ${ }^{81}$ The significance of this perimeter statement was far-reaching -- It implied that Korea and Formosa were both excluded from this defense perimeter or even that the United States would not bother to interfere if the Chinese Communists should take action to capture Formosa. At least the Chinese Communists interpreted it this way. For this statement Dean Acheson was frequently accused of giving "green light" for the North Korean aggression. It seems to most historians that Dean Acheson's speech "was a 
classic failure of deterrence". ${ }^{82}$ At least he was "irrational" as Bruce Cumings looked at it. ${ }^{83}$ No matter what Acheson's real purpose was in this statement, some observers were puzzled by it since "Mao Zedong's impending victory in China would leave the Republic of Korea as the only remaining foothold of democracy in Northeast Asia." ${ }^{84}$

The reason why Dean Acheson made this controversial statement was probably based upon two facts: 1. By that time both the Soviet Union and the United States had withdrawn all their troops from Korea -- if the United States put Korea within its National Defense perimeter, it would be unacceptable to the Soviet Union; 2. The fall of Chiang's regime was only a matter of time -- any further military involvement with the KMT government would hurt the chances of detente between Red China and the United States. Later Dean Acheson apologized for this much criticized speech: "in those days I was fresh and eager and inexperienced. You've left yourself open to a very serious misunderstanding. ${ }^{185}$ Richard Nixon simply called it "a miscalculation". ${ }^{86}$

The Truman Administration was already inclined to abandon Chiang Kai-shek but it was out of the question to recognize mainland China. The anti-Western attitude of the Chinese Communists and its totalitarian Communist conviction were totally unacceptable to the White House policy makers. The Truman Administration did not have any intention to recognize China in late 1949 and in 1950 in spite of advice for recognition from some China experts.

Regardless of the real motives behind the Truman Administration's defense perimeter statement -- whether they had the idea that Mao might develop into another Tito or that the Chinese Communists' interests must conflict with those of the Soviet 
Union or the Soviet Union could not influence China's future destiny, the Chinese Communists were very sensitive of the perimeter speech's significance. The CCP regarded it as a kind of signal or promise that the United States would let Formosa and Korea fall. The CCP lost no time in setting its military goals in 1950 accordingly. The Third Field Army was ordered to station in East China(near Nanjing, Hangzhou and Shanghai) to defend that area and build up a base for the campaign to capture Taiwan; The Second Field Army would follow the Third Field Army to occupy Southeast China and to liberate Sichuan, Guizhou and Yunnan; The Fourth Field Army(with the 4th Corps of the Second Field Army) would go to wipe out the KMT remnants in the Central south of China and be deployed in that region; The First Field Army was supposed to complete the liberation of the Northwest region; and the 2nd Corps of the First Field Army was deployed near Chinhuangdao and Tanggu area(close to Tianjin) to prevent any hostile landing. By June, 1950, the PLA had wiped out most KMT remnants on the mainland and unified the whole territory except Taiwan and Tibet. ${ }^{87}$ Although the CCP planned to capture Taiwan and annex Tibet as soon as possible, Mao and other Chinese leaders realized it needed much preparation since China did not have enough air force or navy(the building up of both just got started) to support its ground forces. At a meeting, Mao pointed out that the liberation of both Taiwan and Tibet was "still a task of serious struggle. ${ }^{188}$ His point was based on the fact that in September, 1949, the PLA had suffered a serious frustration in the Jinmen Campaign in which most of the PLA landing troops (about 10,000 soldiers) were wiped out by the KMT garrison troops as the PLA did not have enough air and 
naval support.

On May 17, 1950, the PLA took Hainan Island, then it took Zhoushan Islands which served as a defensive screen for Formosa. The Formosan Intelligence Department reported a large number of Third Field Army troops concentrated in Fujian province; naval vessels anchored in the ports of the Taiwan Strait; and air planes stationed in the airfields close to the Taiwan Strait. ${ }^{89}$ At this moment most people on Formosa believed that Chiang's regime could hardly survive one more year -- it was but a matter of time and then Formosa would fall.

The sudden outbreak of the Korean War totally changed the destiny of Formosa. It was the Korean war that saved Chiang's regime as the Truman Administration hastily adjusted their Far East policy and their non-assistance policy on Formosa.

On June 25, 1950, when the War suddenly broke out in Korea, both Truman and Acheson were shocked. Their first response was that this was part of the global Communist aggression against the free countries and it must be initiated and sponsored by the Soviet Union. President Truman believed that this crisis was not a civil war precipitated by North Korea. He stated: "The attack upon Korea makes it plain beyond all doubt that Communism has passed beyond the use of subversion to conquer

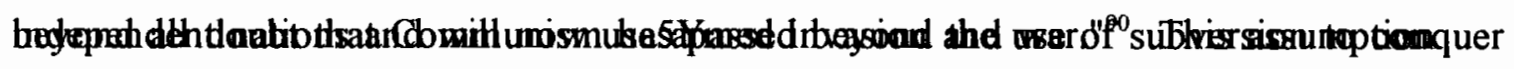
was quite convincing to some observers since by that time "the People's Republic of China, along with the Soviet Union, espoused a doctrinaire of two-camp international outlook, and took an ideologically inspired, revolutionary strong stand against the United States and Japan." ${ }^{11}$ The President felt an urgent need to counter-attack this 
Communist aggression, believing that "the Russians are trying to get Korea by default, gambling that we would offer no resistance. I thought that we are still holding the stronger hand, although how much stronger, it is hard to tell. ${ }^{92}$

The White House reacted promtly. In line with the U.N. Security Council resolution passed on June 25, the President issued the first order:

1. General Macarthur be authorized to furnish the Republic of Korea with military equipment in excess of that already authorized under the Mutual Defense Assistance Program.

2. that American airplanes be employed to cover the evacuation of American women and children from the port of Inchon near Seoul.

3. that the Air Force be authorized to destroy North Korean tanks and airplanes that attempted to interfere with the evacuation....

5. that the Seventh Fleet be ordered to prevent a Chinese Communist invasion of Taiwan as well as a Nationalist assault on the Chinese mainland. ${ }^{93}$

The President's purpose was very explicit -- he intended to restore peace and order in South Korea by fighting a limited war. While holding the Europe-first theory, the President was clear that ".... this is one of the places where the Soviet-controlled Communist world might choose to attack" and that "if the Communists were permitted to force their way into the Republic of Korea without opposition from the free world, no small nation would have the courage to resist threats and aggressions by stronger Communist neighbors. If this was allowed to go unchallenged it would mean a third 
world war, just as similar incidents had brought on the second world war. ${ }^{94}$

Strategically, the dispatch of the Seventh Fleet into the Taiwan Strait was intended as a deterrence to the seeming Domino Effect in East Asia as the President explained himself. Politically, it served as a warning to the Chinese Communists not to take any bold action upon Taiwan as he explained that the seventh Fleet was to "prevent the [Korean] conflict from spreading to that area"95 and that "the determination of Formosa(Taiwan)'s future status must await the restoration of security in the Pacific, a peace settlement with Japan, or consideration by the United Nations." ${ }^{16}$ Nevertheless, Truman did not expect that the neutralization of the Taiwan Strait was one of the factors that contributed to China's determination to enter the Korean Conflict. It not only outraged Beijing, but also made it possible for China to transfer its elite army units from Fujian province into Manchuria. Secondly, the President related the Korean incident to the issue of Taiwan, which naturally enlarged a local conflict into an international crisis. To the Chinese Communists, the issue of Taiwan was an entirely interior affair of China: other countries did not have the right to interfere into this matter. They also believed that they were justified to unify any part of its territory, including Taiwan.

The CCP was especially angry about the sending of the Seventh Fleet into the Taiwan Strait as it firmly believed this was part of the American conspiracy to interfere in China's internal affairs. Open protests were made by Mao Zedong, Zhou Enlai and commentators of Renmin ribao(People's daily) and Guangming ribao(the CCP organization newspaper). All regarded the American action as "imperialist 
behavior" and "Aggression". Zhou Enlai stated: "... I declare that Truman's statement of June 27, and the action of the American Navy, constitute aggression against the territory of China, and a total violation of the United Nations' Charter. This violent, predatory action by the U.S. government comes as no surprise to the Chinese people, but only increases their wrath because the Chinese have, over a long period, constantly exposed all the conspiratorial schemes of the American imperialists for aggression against China and grabbing Asia by force." ${ }^{97}$ Zhou Obviously exaggerated the degree of American involvement in his speech. However, it expressed the resolute determination of the CCP to claim Taiwan as part of its territory: "No matter what obstructive action the U.S. imperialists may take, the fact that Taiwan is part of China will remain unchanged forever. All the people of our country will certainly fight to the end single-minded to liberate Taiwan from the grasp of the American aggressors. ${ }^{\text {"98 }}$

Mao Zedong bitterly criticized the change of U.S. policy on Taiwan. He insisted that "The affairs of Asia should be handled by Asians, and not by Americans. American aggression can not but evoke widespread determined resistance on the part of Asian people. Although Truman announced last January 5 that the United States would not intervene on Taiwan, he himself has just proven the hypocrisy of that statement and at the same time has broken every international agreement by the United States that it would not interfere in the internal political affairs of China." ${ }^{19}$

The Chinese leaders' false understanding of Truman's decision to send the Seventh Fleet into the Taiwan Strait was that the United States Government was determined to defend Taiwan with Chiang Kai-shek and use Taiwan as a springboard 
to invade mainland China. It seemed that an enlarged Korean War would offer Chiang Kai-shek some hope which was none other than the outbreak of a third world war. This suspicion became more convincing to the CCP leadership when Chiang Kai-shek offered to send 33,000 of his elite troops to join the fighting in Korea. The CCP leadership had a big concern about the possibility that whenever the Korean situation turned unfavorable to the North Koreans, the U.N. forces and Chiang's troops might invade Manchuria while Chiang's troops could attack the south of China with the support of the Seventh Fleet. ${ }^{100}$ All this became a warning signal to Beijing that "Reactionaries are going to strangle the New China in its cradle."101

Based upon the above analysis, the CCP leadership was said to have kept a fairly clear mind about the seemingly favorable situation in Korea according to some recently declassified Chinese sources and publications. Mao and other Chinese leaders had expected a possible turn in Korea because of the large-scale military interference of the United States on response to the invasion of South Korea. Under the suggestion of Mao Zedong, the CCP held a National Defence Conference on July 7 and 10, 1950 in Beijing to discuss the situation of the Korean War and the defence of China's territory. Zhou Enlai presided over the conference. Most of the CCP Military Committee members attended the meeting, such as Zhu De, Nie Rongzhen, Lin Biao, Luo Ronghuan, Xiao Hua, and Xiao Jinguang. According to the resolution of this Conference, the CCP Military Committee issued an important order -- "The Resolution to Defend the Northeastern Border" ${ }^{102}$ whose principal measure was to form the Northeastern Border Army by transferring troops from the Thirteenth Army Corps 
(under its command there were the 38th Army, 39th Army, 40th Army and the 42th Army), and 1st, 2nd and 8th artillery divisions. The Northeastern Border Army commanded 250,000 men. Its major tasks were to defend the Manchuria border and to join the fighting in Korea if necessary. ${ }^{103}$ The original commander of the Thirteenth Corps was General Huang Yongsheng. Lin Biao, Luo ronghuan and Liu Yalou all held the opinion that Huang Yongsheng was incapable carrying out the duties of commander-in-chief of the Northeast Border Army and that General Deng Hua was a better choice for it. Based upon their advice, the CCP Military Committee authorized General Deng Hua to be the Commander of the Thirteenth Corps. The reason for using this army Corps was that it once formed an elite unit of the Fourth Field Army, whose soldiers mostly came from Manchuria and were familiar with both the climate and geography in that area. ${ }^{104}$ From this arrangement it is obvious that the CCP's first move after the Korean War broke out was defensive.

Since the CCP took a defensive attitude at the early stage of the War, China showed pretty much restraint to the First U.N. Security Council resolution on the Korean issue. On July 21, 1950, Zhou Enlai made it clear to K.M. Panikkar (the Indian ambassador to China) that the Chinese had every intention of avoiding implication in present hostilities unless forced upon them. ${ }^{105}$ Later, Zhu De, the Commander-in-chief of the PLA, reaffirmed this stand of the Chinese Government. He stated: "There is no need to fear outbreak of world war since decision as to whether such a war would break out is not in America's hands but in ours" and "China would definitely not become involved in world war until fully prepared" and "the 
Chinese troops would not be sent into Korea although Chinese people are sympathetic with the Korean people and would give them other forms of aid." ${ }^{106}$ Zhu's speech can be interpreted as that China was ready and confident to set back any invasion by the United States and that since China was not going to send any of its troops into Korea, the chance of a world war was minimal.

On July 23,1950 , the CCP took another step to strengthen the leadership of the Northeastern Border Army and the Thirteenth Army Corps. Mao Zedong issued an order authorizing Gao Gang as the Commander-in-chief and political commissar of the Northeastern Border Army, Han Xianchu and Hong Xuezhi as deputy commanders of the Thirteenth Army Corps.

The authorization of General Douglas MacArthur to be the Supreme Commander of the U.N. forces caused much concern of the Chinese leadership. Indisputably, the President was going to take advantage of the General's military merits and his long service in Asia. However, Truman neglected one important element of the General -he was totally Asia-oriented, believing Asia to be the major theater to deter the global communist expansion. There was also a basic strategic difference between the president and the general -- the president wanted to check the Communist expansion in Korea by fighting a limited war while the general aimed to achieve a complete victory there. The general stated: "The Communist threat is a global one. Its successful advance in one sector threatens the destruction of every other sector. You cannot appease or otherwise surrender to Communism in Asia without simultaneously undermining our efforts to halt its advance in Europe. ${ }^{107} \mathrm{He}$ occasionally criticized the 
White House policy makers because they "don't understand the Oriental Mind" for their less aggressive strategy in Asia. ${ }^{108} \mathrm{He}$ ardently believed that "War's very objective is victory -- not prolonged indecision. In war, indeed, there can be no substitute for victory." ${ }^{109}$ As a professional soldier, MacArthur was expecting a complete victory over the communists in Korea which required a much wider war into Manchuria -- he did not want to see any type of appeasement there.

In July and August, one incident made the CCP become more alert about their own security. That was the official visit of Douglas MacArthur to Taiwan. The Taiwan news media made full use of this occasion to propagandize their "fine" relations with the United States. Pictures were taken of the General arm in arm with Chiang kai-shek and were carried on the first page of Formosan newspapers. It aimed to give the whole world an impression that "the United States was determined to defend Taiwan with Chiang." personal feeling on this visit: "It was a great pleasure for me to meet my old comradein-arm of the last war, Generalissimo Chiang Kai-shek. His indomitable determination to resist Communist domination aroused my sincere admiration." ${ }^{111}$ To the CCP, the general's attitude was equal to an open challenge to their preparation of the Taiwan Campaign as the general stated: "Arrangements were completed for effective coordination between the American forces ... and those of the Chinese Nationalists." ${ }^{112}$ The general strongly believed that this coordination was able "to meet any attack which a hostile force might be foolish enough to attempt. Such an attempt would ... stand little chance of success. ${ }^{113}$ Chiang Kai-shek lost no time to proclaim that 
"victory is guaranteed by a second-time cooperation with an old friend." 114

Under such a situation, the CCP's plan to capture Taiwan had to be postponed so as to focus on Korea and on the defence of mainland China. Mao told Zhou Enlai that it was totally unfavorable to North Korea to have a stalemate with the U.N. forces as North Korea did not have any air or naval support at all. Mao thought the best opportunity for North Korea to win a quick victory was gone. Mao and Zhou shared the opinion that the United States would try its best to win the war so as to keep its prestige in the Western World and the war would very likely turn unfavorable to North Korea. China should be prepared for the worst. ${ }^{115}$

On August 4, 1950, the CCP Politburo met again to discuss the Korean War development. At the meeting Mao expressed his own opinion that "If the U.S. imperialists won the war, they would become more arrogant and would threaten us. We should not fail to assist the Koreans. We must lend them our hands in the form of sending our military volunteers there. The timing could be further decided, but we have to prepare for it." ${ }^{116}$ Whether those military volunteers were going to be composed of the PLA elements or simply of armed civilians, Mao did not say. Ever since Mao made this statement, it had been taken as the guideline of the CCP for major decisions later. The next day(August 3, 1950), Mao ordered the Northeastern Border Defense Army to complete preparations for war operations in early September. ${ }^{117}$

August 7, 1950, People's Daily Editorial stated that "We Chinese people would like to support, together with all the just governments and just peoples, the proposal 
made by the Soviet Union to solve the Korean problem peacefully, to free the United Nations from the control of the American invaders and restore it back to its role as a defender of peace." ${ }^{118}$

On August 10, Warren Austin, the United States delegate to the United Nations made a statement at the U.N. Security Council that the American government was planning to reunify Korea under U.N. auspices. This was an official signal to Beijing that the United States was going to bring its troops to the doorway of Manchuria. August 20, Zhou Enlai, as China's foreign minister, telegraphed the U.N. security council, officially expressing China's stand to support the Soviet Union's proposal to solve the Korean problem peacefully and insisting that China should be included in the discussion of the Korean issue; military actions must be stopped at once in Korea; and foreign troops must be withdrawn from Korea immediately otherwise it was impossible to solve the Korean problem peacefully. ${ }^{119}$ The CCP hoped this could clarify China's defensive stand and bring the war to a peaceful end.

August 23, the CCP held another meeting to discuss the updated Korean situation. At the meeting some military analysts brought forward the opinion that the United States might be planning a landing somewhere along the western Korean coast in the rear area of North Korean troops. This opinion was immediately reported to Mao. Mao thought it was very likely to happen and instructed the Chinese diplomat in Korea to inform the North Korean leaders. Then Mao issued an order, in the name of the CCP Military Committee, to the Northeastern Border Army headquarters, asking them "to accelerate and complete all the preparations for war before the end of 
September." ${ }^{i 20}$

China's concern about its own security was deepened when the United States airplanes violated the border between China and North Korea. On August 27 and 29, U.S. B-29 bombers entered China's air space near the Yalu River by mistake and bombarded some targets which caused damages to railway installations and wounded civilians. For the first time since the start of the Korean War, the Chinese Government issued strong protests to Dean Acheson and the U.N. Security Council. Then there were nationwide anti-American protest demonstrations in China. This propaganda movement served as public opinion preparation for possible military actions later. A People's China editorial expressed the CCP's apprehension of the possibility that the United States would spread the war to China, relating the fate of North Korea with China's own security issue for the first time:

We must regard the Korean people's defensive war as our war, for the American invasion of Korea is as much a threat to us as it is to the existence of a free and independent Korean nation. That is why the attack on Korea has such sinister undertones for China, why the struggle of the Korean people is bound up with our struggle, and inevitably with the struggle of all Asian peoples against imperialism. ${ }^{121}$

Historian Chen Jian argues that "Even before the American landing at Inchon, CCP leaders were inclined to enter the war." ${ }^{22}$ His point is based upon the Memoirs by Bo Yibo, a senior member of the CCP, that on August 4, 1950, the CCP Politburo met to discuss the Korean situation. At the meeting Mao expressed his opinion that China should help North Korea "in the form of sending our military volunteers there". ${ }^{123}$ Actually this was only Mao's personal opinion -- it was far from a final decision of the CCP Politburo. Up to now no declassified Chinese sources indicate 
that the Politburo reached any intervention resolution before October. Even after Mao sent a cable to Stalin on October 2, 1950 to inform him of CCP's decision to enter the war, there were still different opinions and debates within the CCP leadership as some of them worried about a possible defeat. ${ }^{124}$ Further evidence is back in June, 1950, the CCP Military Committee decided to demobilize 1.4 million of its army in order to lower down the burden of military expenses and develop its civilian production. This order was actually carried out on June 21,1950 , only four days before the outbreak of the war. ${ }^{125}$ The PLA demobilization in late June indicates that the CCP was not informed by Kim Il Sung of the exact date of the North Korean invasion and that the Chinese army was not ready for any large-scale military involvement at least in the summer of 1950. A third evidence is that in late August, Nie Rongzhen, the then PLA deputy Commander-in-chief made a suggestion to the CCP Central Committee to get prepared for a possible turnover of the situation in Korea. Based on his suggestion, the CCP Military Committee issued orders to move the Ninth Army Corps(20th, 26th and 27th armies) under the commander of Song Shilun from Fujian province into areas along the Jinpu Railway, and transfer the Nineteenth Army Corps(63th, 64th and 65th armies) under the command of Yang Dezhi from Northwest China to areas along the Lunhai Railway. The Song Army Corps had been deployed in Fujian for the preparation of the Taiwan Campaign while the Yang Army Corps had just completed their tasks of wiping out the KMT remnants in the Northwest region. These two army corps were going to be used as the second echelon of the Northeastern Border Army. Arrangements were made along the southeast coast of China in case there was assault 
from Taiwan. ${ }^{126}$ August 26, Zhou Enlai, as the vice chairman of the CCP Military Committee, presided at a national defence meeting to check the preparations of the Northeastern Border Army. At this meeting decisions were made to order more military equipment so as to speed up the construction of China's air force, artillery units and armored troops. ${ }^{127}$ Obviously, Mao himself was inclined to confront the United States, but not necessarily in Korea.

September 7, Chai Chengwen, an military attache of the Chinese Embassy in Korea, was summoned back urgently to Beijing from Korea. He brought back with him a headline report which was prepared by the Chinese Ambassador to North Korea, Nie Zhiliang. This report analyzed North Korea's difficulty in continuing the war and the possibility of a U.S. landing in the rear of the North Korean Army. Nie's report was sent to Mao and other CCP leaders and caused much attention. Zhou Enlai and Lin Biao had interviews with Nie. Zhou was mostly concerned about the question of what would be the biggest problem if China had to enter the war. Nie answered that the biggest problem would be transportation, interpreters and supplies that the present conditions in Korea made it almost impossible for a large-scale military operation. Lin Biao's question was whether Kim Il Sung was prepared to go on with guerrilla warfare in the mountains if China preferred not to send troops into Korea. While being unable to answer this question, Chai felt some controversy in the forthcoming decision by the CCP Politburo. ${ }^{128}$

However, China did not take the decisive step to get involved in the Korean conflict before the U.N. forces' landing at Inchon. There were several reasons. First, 
the Chinese troops which were already deployed along the Yalu border were not completely ready although they had been pushed by Mao for early readiness.

Secondly, there had been constant arguments within the CCP leadership about whether China should send troops into Korea, which hampered the decision making process. Lastly, the CCP leadership had been waiting for the request from Kim Il Sung for that but it did not come until after the Inchon landing. Evidently, the CCP leadership believed that Kim, as a staunch nationalist in both the Second World War and the Korean War, seemed to prefer to fight the war out with his own strength as long as the military situation was favorable to his troops. His attitude was understandable to the CCP leaders since they were nationalists themselves. Nevertheless, facing a nationalist like Kim II Sung, the CCP had no other alternative but to wait until Kim could no longer hold on. ${ }^{129}$ 


\section{CHAPTER IV}

\section{AFTER INCHON LANDING}

The Inchon Landing took place on September 15, 1950 as expected by the Chinese leaders. In a few days the North Korean defense was crushed since they had been too confident for a complete victory and not prepared for such a setback. This caused great concern in the CCP. On September 17, South Korea President Rhee announced that the South Korean Army would continue the attack upon the remnants of the North Korean troops with or without U.S. assistance. ${ }^{130}$ In the meantime, the CCP's appeal to participate in the U.N. discussions on the Korean issue was rejected.

Under this new situation the CCP had to view the development of the Korean Conflict from a new respective: the safety of Manchuria bordering Korea could be severely threatened by U.N. forces' rapid advance and it was therefore very likely that China would need to use its armed forces to help North Korea, the idea being that if North Korea could hold on, there would be no problem to China's security. As I mentioned in earlier chapters, the CCP leadership believed that the United States was not trustful for its promises. On September 17, the CCP Military Committee decided to send a group of military officers to Korea in order "to get familiar with the general situation, make surveys of Korean topography, and prepare for future battle." ${ }^{131}$ The same night, Gao Gang had a special meeting with Chai Chengwen who had been working as the Chinese military attache to North Korea and was going back to Korea 
with the PLA military officers. Gao Gang showed him a letter from Mao Zedong in which Mao said it was inevitable that troops be sent into Korea and preparations should be completed as soon as possible. ${ }^{132}$ We should give credit to Chai Chengwen for the credibility of this top secret message from Mao himself. Chai participated in the Panmunjom Negotiations as one of the Chinese negotiation officials. After his retirement from the Army he devoted himself to international strategy research. In 1993 he published "Panmunjom Negotiations" which is regarded in China as one of the most authentic works on the Korean War. Mao's idea of the Korean situation could be explained for the following reasons: 1) the Chinese lacked reliable information about the real intention of the U.N. troops; 2)Mao purposely exaggerated the possibility of U.S. invasion into mainland China because he needed this to stir up internal sentiment and strengthen his control at home; and 3)Mao knew Kim Il Song's troops were no match for U.N. troops --- they would eventually be crushed.

Although Mao himself was inclined to join the war as soon as possible, other members of the CCP leadership preferred to wait in order to make better preparations. On september 20, approved by Mao, Zhou Enlai sent a personal letter to Kim Il Sung, suggesting that the war was going to be protracted. It had better be conducted on the basis of self-reliance. Zhou further proposed that in every campaign and battle, temporary superiority in both manpower and firepower must be concentrated so as to break up and destroy the enemy. Only by weakening the enemy gradually, could a protracted war be carried out. ${ }^{133}$ Zhou's letter to Kim shows that by September 22, the CCP had not made the final decision yet. The CCP still hoped Kim Il Sung could hold 
on. However, one decision was immediately made by the CCP. They decided that warnings should be sent out to the enemy first before China actually entered the war. This strategy aimed to deter the United States, letting it know that China was serious about the matter. The CCP was hoping that the United States would stop at the 38th parallel after they got these threats. China was still open to the idea of settling the Korean problem via negotiation because no Chinese leader was confident that they could guarantee victory if China declared war on the United States. ${ }^{134}$

When Seoul was re-captured by the U.N. forces, China got word from the Indian Premier Nehru that the U.N. forces would not cross the 38th parallel. ${ }^{135}$ Before that the CCP had held meetings to discuss the possibility whether the United States would stop at the 38th parallel and turn to diplomatic means to solve the problem. Nehru told China that the answer was "Yes" -- the U.N. forces would not cross the line unless they were instructed by the United Nations. ${ }^{136}$ The information provided by the CCP Intelligence Department had a different interpretation -- From September 12 to September 18, the foreign ministers of the United States, France and Great Britain held meetings in New York. At the meetings Dean Acheson tried to convince the other two foreign ministers about the importance and necessity of crossing the 38th parallel. The three foreign ministers reached common understanding about the issue finally. ${ }^{137}$ This information made the CCP leaders believe that the United States was attempting to hold China from taking any action before the U.N. forces wiped out North Korean Army. ${ }^{138}$ Based on this information, the $\mathrm{CCP}$ leaders thought they were made a fool of by India and the United States. 
In his Reminiscences, MacArthur explained the prevalent opinion in the United States at that time: "When, after Inchon, no diplomatic action looking toward peace seemed to be forthcoming, diverse views began to appear among the members of the United Nations. The United States took the position that if the North Korean Army was not completely destroyed, and peace and order restored in the northern half of the peninsula, South Korea would live indefinitely beneath the threat of renewed Communist aggression." ${ }^{139}$ This argument was the basis of the strategy to cross the 38th parallel so as to wipe out the remnants of the North Korean Army.

On September 27, 1950, the Indian Ambassador Panikkar made a request to see General Nie Rongzhen, the deputy Commander-in-chief of the PLA. In their meeting they discussed the updated developments of the Korean War. Panikkar seemed to mention an incident of the Third Chinese Civil War by chance. He recalled that when Nanjing was taken by the PLA in 1949, MacArthur once told a U.S. News Agency reporter: "Give me 500 air planes and they will be crushed." 140 MacArthur apparently referred to the Chinese Communists as "them". To Panikkar's question, General Nie's answer was: "We even regard the atomic bomb as 'a paper tiger', not to say a few hundred air planes." 141 Panikkar frankly told Nie that the major industry of China was either along the eastern coast or in Manchuria. When war occurred, these industrial installations would easily be damaged, which would delay China' economic development for at least 8 to 10 years. Nie answered that if the United States chose to have war with China, China would have no other alternative but to resist. He also pointed out that this was only one side of the question. On the other hand, the 
imperialists had their own weak points. China's task was how to maintain peace and prevent the war from happening and expanding. ${ }^{142}$

What his real purpose in this interview was, Panikkar did not mention in his autobiography. The CCP's interpretation was that he mentioned MacArthur's statement of the fall of Nanjing on purpose as it was good timing with Truman Administration's preparations to cross the 38th parallel -- Panikkar seized on the MacArthur statement to exaggerate the risk of war with the United States or give China some hint that China had better not get involved directly. ${ }^{143}$

In his memoirs, Panikkar also mentions that General Nie made it clear to him that "China did not want to sit back with folded hands and let the Americans come up to their border"144 which gave Panikkar the impression that "the Chinese proposed to intervene in the war. ${ }^{145}$ General Nie also expressed China's determination to carry out the war at any costs:

We know what we are in for, but at all costs American aggression has to be stopped. The Americans can bomb us, they can destroy our industries, but they cannot defeat us on land .... They may even drop atom bombs on us. What then? They may kill a few million people .... China lives on the farms. What can atom bombs do there? Yes, our economic development will be put back. We may have to wait for it. ${ }^{146}$

Nie's words should be dealt with as an official statement by the Chinese

Government. By that time Nie was one of the three vice Chairmen of the PLA Military Committee which was the supreme agency to make strategic decisions.

In order to make sure the United States got the exact message the CCP aimed to get across, Zhou Enlai made a formal statement on the Korean issue on September 30, 
1950, at the Chinese People's Political Consultation Conference's Celebration

Ceremony for the 1st anniversary of the founding of the People's Republic of China. Zhou declared: "... the Chinese people .... want to rehabilitate and develop their industrial and agricultural production and cultural and educational work in a peaceful environment, free from threats. But if the American aggressors take this as a sign of the weakness of the Chinese people, they will commit the same fatal blunder as the Kuomintang reactionaries. The Chinese people love peace; in order to defend peace, they are never scared in their resistance to foreign invasions; the Chinese people will not tolerate any foreign aggression nor will they supinely tolerate seeing their neighbors being savagely invaded by the imperialists. ${ }^{147}$ Zhou's speech caused a significant response from the foreign news media which captured the important information in his speech. It served as an ultimatum to the U.N. forces --- China was for a peaceful solution of the Korean problem but it would not tolerate the U.N. forces crossing the 38th parallel. If the United States should do so, China would intervene with all its strength.

China's warnings were apparently ignored by the United States as the U.N. forces were continuing to advance northward. The Truman Administration seemed to be willing to risk a clash with China and gambled on a possible complete victory. On September 27, General Marshall suggested to the President that he should authorize MacArthur to advance north of the 38th parallel. It was approved immediately by the President. On September 29, Marshall sent a telegram to MacArthur, instructing him that "We want you to feel unhampered tactically and strategically to proceed north of 
the 38th parallel." ${ }^{148}$ On September 30, the Third Division of the South Korean Army crossed the 38th parallel. On October 1, MacArthur issued his ultimatum to the North Korean Army to surrender:

The early and total defeat and complete destruction of your armed forces and war-making potential is now inevitable.... I ... call upon you and the forces under your command ... to lay down your arms and cease hostilities under such military supervision as I may direct .... to avoid the further useless shedding of blood and destruction of property. ${ }^{149}$

This ultimatum was unacceptable to North Korea. At midnight of October 1, Kim Il Sung met the Chinese Ambassador Ni Zhiliang crucially. He said: "MacArthur demanded me to raise our hands but we never have such a habit." ${ }^{150}$ Then Kim II Sung and Piao Xian Yong (Vice premier of North Korea and at one time the leader of the Korean Communist Party in the south) made a joint request to the Chinese Communist Party for help, hoping China could dispatch the Thirteenth Army Corps across the Yalu River as soon as possible. ${ }^{151}$ In the cable Kim sent to Mao and the CCP, He said: " .... the landing troops of the enemy have cut off our connections with our troops in the south, some of them have been wrapped up by the enemy.... The enemy is intending to advance further north..... We are trying every means to prevent our country from being colonialized by shedding the last drop of our blood..... If the enemy ... advances to attack areas north of the 38th parallel, it is extremely difficult for us to stop it by our own strength. Therefore, we have to make an urgent request to you for special help from China -- We hope you can send the PLA to help us fight the enemy directly when the enemy attacks areas north of the 38th parallel."152 
The CCP and Mao Zedong then realized that the North Koreans could hardly hold on. If they did not offer to help to Kim Il Sung, North Korea would perish soon. After reading the cable from Kim Il Sung, Mao immediately consulted Zhou Enlai and Liu Shaoqi. After brief discussion they made the decision that China should send part of the PLA under the title of Chinese Volunteers into Korea to fight the United Nations. This decision was approved by the CCP Politburo at once. The Chinese People's Volunteer Army was actually composed of the same units of the People's Liberation Army except the title. They were designated "Volunteers" out of the consideration of the Soviet Union which was bound by the recently signed Sino-Soviet Mutual Assistance Treaty to intervene if China was in a state of war with a third party, something Stalin was quite reluctant to do. A Chinese army composed of "volunteers" could save the Soviet Union this obligation since ostensibly the Chinese Government had nothing to do with these "volunteers". Secondly, the title of the Chinese People's Volunteer Army might not give the United States any excuse to declare war on China, to expand the war into Manchuria, or launch the third World War at its will. Mao and other Chinese leaders were clear that a third world war was just what Chiang Kai-shek had been expecting because only a general war between the United States and the Chinese Communists could possibly bring back his power. ${ }^{153}$ Thirdly, a general war definitely would increase U.S. military assistance to Chiang Kai-shek and form a greater menace to China's security. ${ }^{154}$ Lastly, it also showed that the CCP leaders intended to limit the conflict within a local or regional scope.

On October 2, 1950, Mao sent a cable to Stalin, informing him of China's 
decision to dispatch combat troops into North Korea: "We have decided to send part of the armed forces into Korea, under the title of Volunteer Army.... If we allow the United States to occupy all of Korea, Korean revolutionary power will suffer a fundamental defeat, and the American invaders will run rampant, and have negative effects for the entire Far East." ${ }^{\text {15s }}$ This cable showed the determination of the CCP to contain the spread of capitalism by the United States at any costs: "... since Chinese troops will fight American troops in Korea, we must be prepared for the United States to declare and enter a state of war with China. We must be prepared that the United States may, at a minimum, use its air force to bomb many major cities and industrial centers in China, and use its navy to assault the coastal region."156 Mao's anticipation of the worst possible development of the intervention was that the Chinese Army would be "unable to destroy the American forces of large number, the two armies [were] in mutual deadlock, and the United States had already entered an open state of war with China, leading to the destruction of the economic development plan we have already begun."157

According to Chai Chengwen, a Chinese military attache in Korea, no order was issued to the Thirteenth Army Corps to advance into Korea after Mao Zedong made the decision, nor was North Korea informed of it. ${ }^{158}$ The reason was that the CCP did not want to make any rash move before it could guarantee sufficient military assistance from the Soviet Union in terms of military equipment and Soviet air cover as had been promised by Stalin during Mao's stay in Moscow. Mao hesitated for a while because this was a big decision concerning the lives of hundreds of thousands of 
people. If China won the war, there was nothing to lose; If China could not win it, it would be a danger to threaten the stability of the government or even to lose the control of the whole country. ${ }^{159}$ Mao also told Stalin that the Chinese People's Volunteer Army was going to enter Korea on October 15, 1950(It was postponed to October 19,1950 due to supply and transportation problems). 12 divisions(already transferred to south Manchuria) were going to be dispatched as the first attacking group, numbering 260,000 men. In this cable it was clear that the CCP did regard the 38th parallel as the limit for the U.N. forces' advance northward as Mao asserted: "They(the 12 divisions) will be stationed in appropriate districts of North Korea, not necessarily all the way to the 38 th parallel. While they do combat with enemy who dares to advance north of the 38th parallel... they will await the arrival of Soviet weapons... and then coordinate with Korean comrades for a counterattack, destroying the invading American Army." Mao also confirmed that he was going to transfer another 24 divisions "in order to form the second and third waves of military forces to assist Korea." 160

In the light of this decision, Zhou Enlai called the Indian Ambassador Panikkar for another urgent interview at $1 \mathrm{AM}$ October 3, aiming to inform the United States of this decision via Panikkar whom the Chinese leaders regarded as an unofficial diplomatic channel. At that time India was the only country through which China could get across its important message to the United States as India was keeping fairly good official relations with both China and the United States. Zhou told Panikkar: "Among the questions brought forth by your Premier Nehru in the last interview one 
was very urgent. It was the issue of Korea. The United States is intended to cross the 38th parallel and to enlarge the war. If they really want to do so, we can not stand idly watching. China would surely interfere. Please convey this to your Premier."161 Zhou then added: "We stand for a peaceful solution of the Korean Problem, and make it a local issue. We are still holding this opinion. The Korean War must be stopped; Foreign troops must be withdrawn, which will be beneficial for the peace in the East." ${ }^{162}$ When Panikkar asked whether China intended to intervene if only the South Koreans crossed the parallel, Zhou made it very clear: "The South Koreans do not matter but American intrusion into North Korea would encounter Chinese resistance." 163

The CCP hoped that this message could reach the White House through Panikkar. It did actually. But the Truman Administration did not take it seriously because Panikkar was not a person credible for this information as he "in the past played the game of Chinese Communists fairly regularly, so that his statement could not be taken as that of an impartial observer." ${ }^{164}$ Based on this argument, the threatening warning from China was regarded only as "a bald attempt to blackmail the United Nations by threats of intervention in Korea."165

Although Mao was determined to confront the United States and help North Korea and it was approved by the CCP Politburo, there were obviously different opinions in the CCP Politburo. In order to reach a common understanding of the strategy, the CCP held a series of meetings at Yiniantang of Zhongnanhai(where Mao and other CCP leaders lived)from October 2 to 8,1950 . Those who were present at 
the meetings included Chairmen of the major regions of China, and CCP Politburo members. On October 3, Mao made the decision to summon Peng Dehuai to fly to Beijing from Xian(where he was the Chairman of the Northwestern Region Government). ${ }^{166}$

At one of the meetings Zhou Enlai analyzed the intention of the United States as "by using the bases in Japan, the United States inherited the adventurism of the Japanese militarists, following the history since the war of 1895 and took the track of conquering China, namely, to occupy North-east China(Manchuria) before annexing China and to occupy Korea before grabbing North-east China .... For us, the Korean question is not simply a question concerning Korea, it is related to the Taiwan issue. The U.S. imperialists have adopted a hostile attitude towards us and set up their defence line in the Taiwan Strait while paying lip service to non-aggression and nonintervention. From information we got, they wanted to calm China first and after occupying North Korea, they will come to attack China." ${ }^{167}$

Zhou's analysis was quite acceptable at that time in the CCP. It again proved that the issue of their territory security was the priority concern in the CCP's policy making procedure in early 1950 . However, no declassified U.S. governmental documents yet show that the United States was intending to invade China after occupying Manchuria before China's intervention.

At another meeting, both Mao and Zhou expressed the concern that even if the United States did not attack [China] immediately, it could establish a hostile regime on the Korean peninsula and deploy its troops along the Sino-Korean border to exert 
military pressure that would be a major threat to northeastern China and that it was very hard to defend the border of North-east China which is more than one thousand kilo-meters long. How many troops would be enough to defend the Sino-Korean border? It was also not applicable "to wait there year after year without knowing when the enemy will come." ${ }^{168}$ Both Mao and Zhou agreed that a passive defence was almost impossible. Then Zhou quoted the French News Agency that the United States would go to defend other important areas such Taiwan and Indo-China when the Korean War was over. If that news was true, China would have to confront the United States either in Taiwan Strait or in Viet Nam. If China wanted to break the three-direction encirclement by the United States(from Viet Nam, Taiwan, and Korea ), it was better to fight the U.S. in Korea as it was mountainous and favorable for China's mobile warfare strategy. ${ }^{169}$

When Mao asked those who were opposed to intervention to summarize their points, Gao Gang stressed China's inferior economic potential, inferior military power and much less consolidated rear defense. Gao Gang and Lin Biao shared the opinion that China had better adopt a strategy of strengthening the border defence as the Chinese Army could not compete with the U.S. Army. To plunge into the war without sufficient military strength was equal to bringing the trouble to China. Obviously, nobody could guarantee a victory for a war with the United States. This point was supported by some of the CCP Politburo members at the meeting. ${ }^{170}$ Some Politburo members pointed out that the United States had emerged from the Second World War as the most powerful country in the world. Its annual steel output in 1949 
reached 87.72 million tons, which was more than 144 times that of China. The difference between the two countries was even greater in electricity, petroleum, other industrial products and grain output while in 1949, China's agriculture and industry could barely satisfy its domestic needs. ${ }^{171}$ They quoted the above figures in order to prove that China could not afford a large-scale war. Other Politburo members held the opinion that it was better to ask the Soviet Union to intervene instead since the Soviet Army was better equipped. Besides, the unstable political situation in the newlyliberated areas of China was still a major threat to the existence of the people's Republic of China -- there were constant sabotage activities initiated by the KMT remnants in the Southwest region. And other CCP politburo members held the opinion that the major threat was from Taiwan, not from Korea. ${ }^{172}$ Despite the different viewpoints mentioned above, most of the CCP leaders at the meeting shared the fear of the United States' military strength in terms of its air and naval dominance and the atomic bomb. The Chinese Army's firepower on the ground was also inferior to that of the U.S. Army -- in 1950, one PLA Army Corps had 198 artillery pieces, about one tenth that of the similar American unit which possessed 1428 artillery pieces. $^{173}$

When Mao suggested Lin Biao as the Chinese Volunteers' commander, Lin declined, with an excuse of illness -- the actual reason was that Lin was afraid that he might not win a war with the United States, which would disgrace the military merits he gained in the past. Lin soon left Beijing for Moscow on a recuperation trip. Mao later told Peng Dehuai that Lin Biao was over-cautious in micro strategy, lacking 
aggressiveness in macro strategy. ${ }^{174}$

In late 1952, Liu Shaoqi, while on his official visit in Moscow for the Nineteenth Congress of the Communist party of the Soviet Union, told Wang Ming(former CCP general secretary) that Mao was "wracked by indecision even after the [U.N. forces'] Inchon landing and the initial U.S.(This should be U.N. here but unfortunately, all Chinese sources recorded it as U.S.) thrust across the 38th parallel." ${ }^{175}$ According to Liu Shaoqi, Mao did not want to fully engage the U.S. forces unless he was forced to. ${ }^{176}$

Mao's unwillingness to confront the United States on a large scale did not mean that he preferred to wait or look on. He agreed to the disadvantages for intervention brought forward at the meeting but said: "What you have said sounds reasonable. But it would be shameful for us to stand by seeing our neighbors in perilous danger without offering any help." ${ }^{177}$ Mao told his cadres that if China let the United States occupy North Korea without doing anything, "internationalism would be empty talk." 178

In fact North Korean Communists offered great help to the CCP in the 1940s -Kim Il Sung himself fought the Japanese as the vice commander of the Chinese Northeastern Anti-Japanese Army in Manchuria in the second World War, ${ }^{179}$ in the Third Chinese Civil War, when the PLA was temporarily retreating under great KMT military pressure in southern Manchuria, Kim let the Chinese Communists use Korean territory as a preparation base for counterattacks later. ${ }^{180}$

Mao again emphasized that there were some advantages in fighting the United 
States in Korea. Mao believed that according to the situation as it developed in Korea, a direct confrontation with the United States was inevitable. After Truman's dispatch of the Seventh Fleet into the Taiwan Strait and MacArthur made belligerent remarks on Taiwan, such a confrontation was but a matter of time. Mao pointed out that among the three most likely fronts where the United States might attack China were Korea, Viet Nam and Taiwan. Mao thought Korea was a better place to counterattack the U.S. because it was mountainous and covered with thick forests(which favored China's mobile strategy and did not favor the U.S. mechanized troops), and because it is close to the Soviet Union and Manchuria. ${ }^{181}$

As the conclusion, Mao asserted: " The question now is not whether we should send troops to Korea or not, but how fast we can do this. One day's difference will be crucial to the whole situation. Today we will discuss two urgent questions -- when should our troops enter Korea and who should be the commander."182 At this meeting Peng Dehuai was considered to be the CPV commander. ${ }^{183}$

Peng Dehuai arrived in Beijing at 4 p.m. October $4,1950 .{ }^{184}$ He was immediately asked to attend the meetings of the CCP Politburo. Mao's remarks deeply impressed Peng. After spending a sleepless night in Beijing Hotel, Peng appeared to be a firm supporter of Mao at the resumed meeting next afternoon. Peng stated his own opinion that it was absolutely necessary for China to enter the war to help North Korea. He argued that if China could not defeat the United States, the worst thing would be that we would lose power in China and we have to fight Chiang Kai-shek all over again. However, if the United States was allowed to deploy its troops in Korea along the 
Yalu River border and on Taiwan, it was very convenient for it to invade China with any excuse. ${ }^{185}$ Peng then argued that at that time the whole situation was more favorable to China because the United States needed a quick war while China preferred a protracted war; that the United States was only good at regular wars while the PLA was good at guerilla warfare while Korea's mountainous geography was more suitable for guerilla wars; and that spiritually, the socialist camp was more powerful than the capitalist camp. Peng then added that if China did not send troops to Korea, how could the strength of the socialist camp be shown to the world? ${ }^{186}$ Feeling more confident, Mao once again pointed out that the Korean problem concerned not only the security of China, but also the fate of the confrontation between the socialist camp and the imperialist camp in the east. Mao said the superiority of China lay in its manpower, moral strength and firm support from people at home, which would compensate for China's unfavorable factors in weapon and equipment. ${ }^{187}$

On October 7, 1950, the United Nations Security Council passed its second resolution on the Korean issue, authorizing its members to "take all appropriate steps" to restore peace in Korea. The same day U.S. troops crossed the 38th parallel. This resolution aimed to unify Korea. The $\mathrm{CCP}$ leadership realized that its serious warnings to the United States did not work and it was impossible to reach a peaceful solution of the Korean problem when the U.N. forces advanced to the 38 th parallel. ${ }^{188}$

On October 8, Mao issued the order to send the CPV into Korea. The order said: ".... in order to safeguard the interests of the Korean people, the interests of the Chinese people, and the interests of all the peoples in the East, the Northeastern 
Border army is now transformed into the Chinese People's Volunteer Army and must set out to move into Korea and fight the invaders side by side with the Korean comrades towards a glorious victory ...." ${ }^{189}$ According to this order, the CPV was composed of the 38th, 39th, 40th and 42nd armies( under the command of the Thirteenth Army Corps), and the Northeastern Border Army Artillery Headquarters(under whose command there were the 1st, 2nd and 8th artillery divisions). Peng Dehuai was appointed to be the commander-in-chief of the CPV; Gao Gang, as the commander and political commissar of the Northeastern Army Region, was ordered to take charge of the rear-area supporting work, namely, food and ammunition supplies, and transportation. ${ }^{190}$

The same day, Mao sent a cable to Ni Zhiliang, the Chinese Ambassador to North Korea, asking him to inform Kim Il Sung of the CCP's decision to send troops and the suggestion for Korea to send Piao Yi Yu to Shenyang to discuss with Peng Dehuai about coordination between the North Korean Army and the CPV. Peng flew to the CPV headquarters in Shenyang at once. ${ }^{191}$

Almost at the same time when Mao issued this order, the CCP received a cable from Stalin which informed the CCP that the Soviet air force was not ready for coordination with the CPV in Korea. ${ }^{192}$ Mao and Zhou Enlai felt surprised and frustrated. Mao said to Zhou: "We have to think over this matter all over again."193 After a short discussion, it was decided that Zhou should go to Moscow to meet Stalin at once.

Zhou set off for Moscow immediately, accompanied by Shi Zhe, Zhou's 
interpreter, and Kang Yimin, Zhou's secretary. Zhou was joined by Lin Biao in Moscow who was staying there for medical treatment. The next day Zhou and Lin went to Stalin's residence and had an interview with him. According to Shi Zhe, the atmosphere of the interview was at first a bit tense because they were not sure of each other's intentions. Stalin first presented a brief analysis of the Korean War situation. Then Zhou Enlai dissembled, saying that the Chinese leadership was constantly being informed of the Korean War situation. Then he expressed the CCP's opinion that Mao Zedong and the CCP Politburo had decided not to send ground forces into Korea since China did not have air force available, nor had China's economy fully recovered from damages of war in the last two decades. Besides, if China could not win a quick victory in Korea, it would involve more friendly countries (referring to other communist countries that would assist China). ${ }^{194}$ What Zhou said was only an excuse. The real implication was if China could not get enough Soviet air cover for its ground forces, China would not enter the war as it would cost much more Chinese lives. Stalin understood this hint immediately. He said that the Soviet Union had not only withdrawn all its troops from Korea but had openly stated there was a complete withdrawal of its troops from Korea. Now it was very difficult for the Soviet Army to reenter Korea as it was equal to confronting the United States directly. ${ }^{195}$

What Stalin really feared was that any violation of the sphere of influence agreed upon at the Yalta conference would start the third world war. Shi Zhe recalled that Stalin suggested a solution to the problem that it was better to send part of the Chinese Army into the war and the Soviet Union would provide weapons and other 
kinds of equipment. Stalin also agreed to provide limited air cover for the Chinese ground forces but the Soviet airplanes would only protect the CPV's rear areas and would not go deep into the enemy's areas. Stalin argued that if the Soviet airplanes were knocked down by the U.S. and the Soviet pilots were captured, it would give the whole world the impression that the Soviet Union was directly involved in the conflict. ${ }^{196}$ Stalin then made further suggestions of how to coordinate. He implied that the Soviet Union was still holding large quantities of left-over weapons and ammunition from the Second World War and Korea was a suitable place to use them. ${ }^{197}$ However, this interpretation by Shi Zhe seemed to be contradictory to the resolution(to enter the Korean War)reached by the CCP Politburo one day before.

Other sources have a different interpretation on this. Those sources show that Stalin did have a meeting with Zhou Enlai. The meeting lasted from 7 p.m. October 9 to 5 a.m. October 10. Zhou started, as planned with Mao, to discuss with Stalin the actual number of fighters and bombers the Soviet Union could dispatch into Korea and who should command these airplanes. When Zhou mentioned this to Stalin, the latter replied that the Soviet air force could not be sent to Korea now because it needed more time to get ready. However, Stalin promised to deliver military equipment for 20 Chinese divisions first. Zhou tried his best to change Stalin's mind but failed. Having no intention to offend Stalin, Zhou tactfully expressed the CCP's opinion that if the Soviet Union could not provide air cover, China was unable to enter the Korean War. ${ }^{198}$ Stalin said that the air cover matter could be further discussed later and he ordered his foreign minister to inform the Soviet Joint Chiefs of Staff to speed up the 
training of the Chinese air force. Then Stalin asked Zhou whether they should inform Kim Il Sung to be prepared to set up their exile government in Tonghua area of Manchuria. Realizing the dilemma facing both China and the Soviet Union, Stalin said that the best solution of the Korean problem was the invasion (U.N. forces' advance north of the 38th parallel) be stopped and a world war avoided on the basis that this solution would not hurt either China's or Soviet interests. ${ }^{199}$ Seeing that it was almost impossible to change Stalin's mind, Zhou left Stalin's residence and immediately cabled Mao Zedong for further instructions. ${ }^{200}$

After receiving confirmed information of the Sudden change of the Soviets, Mao and other CCP leaders were wondering if they should go ahead on their own without protection of the Soviet air force. Mao cabled to Peng Dehuai, Gao Gang and other CPV generals at 8 p.m. October 12,1950, asking them to stop all intervention preparations. Peng and Gao were ordered to go back to Beijing immediately to attend a Politburo meeting. ${ }^{201}$ Before Peng Dehuai left Shenyang for Beijing, he had met the North Korean security minister Piao Yi Yu who hurried there on October 12. $\mathrm{He}$ informed Peng that after crossing the 38th parallel, the U.N. forces and South Korean troops were quickly advancing to the north. The North Korean Army with only 50,000 soldiers retreated from the south. Kim Il Sung and the Korean Communist Party asked the CCP to send the CPV into Korea as soon as possible. ${ }^{202}$

The CCP Politburo held an emergency meeting on October 13 to discuss whether China should cross the Yalu River without Soviet air support. The meeting lasted overnight. At last Mao and other CCP leaders decided that they should go on without 
Soviet air support as they all realized that they should make some sacrifice to defend their territory and to save their newly founded regime. Peng Dehuai at once called Xie Fang, his chief of staff, to continue preparations for the first CPV units to cross the Yalu River. ${ }^{203}$

This decision meant China would make more sacrifices without Soviet air cover. The quick decision of the $\mathrm{CCP}$ also suggested that the $\mathrm{CCP}$ used the non-intervention policy as a bargaining term in Zhou's meeting with Stalin in order to get more Soviet military assistance. Nevertheless, the sudden change of Stalin's attitude made the CCP believe that Stalin was a selfish person. This left a deep gap between the two parties, which eventually led to the total split of relations in the middle of the 1960's. 


\section{CHAPTER V \\ THE FINAL DECISION}

On October 13, 1950, Mao sent a cable to Zhou Enlai in Moscow, informing him that the majority of the CCP Politburo members were in favor of direct Chinese entry into the Korean War even without Soviet air support: " I have consulted with comrades in the Politburo. We unanimously believe that having our troops enter Korea is still more advantageous .... In the first stage we can concentrate on wiping out the puppet army (South Korean Army), for we may deal with the South Koreans with certainty. We can establish bases in the vast mountainous areas north to the line between Wonsan and Pyongyang. This will surely encourage the Korean people. As long as we can destroy a few divisions of the puppet army, the Korean situation can take a turn to our advantage. The above positive policy will be very advantageous to China, to Korea, and to the East." ${ }^{204}$

Mao further stated: "If we don't send troops, allowing the enemy to press to the Yalu Border and the arrogance of reactionaries at home and abroad to grow, this will be disadvantageous to all sides. Above all it will be most disadvantageous to Manchuria; all of the South Manchuria electricity will be destroyed."205

Zhou Enlai studied this cable very carefully and ordered it to be translated into Russian at once. Then Zhou made arrangements to meet Molotov and requested for an emergency interview with Stalin. The same evening, Zhou met Molotov who said 
the message had been sent to Stalin but so far there was no reply. Zhou did not mention his earlier request to have a meeting with Stalin. Instead Zhou brought forth the matter of what equipment and weapons the CPV needed. Molotov replied that since Stalin had already discussed with Zhou the issue of dispatching Chinese Volunteers into Korea, there should be no problem regarding Soviet military assistance but he stressed that everything should be decided by Stalin himself. When the actual number of artillery pieces and tanks the Chinese side needed was discussed, Molotov said it seemed to him there was some difference between the figures Zhou was using this time and the figures discussed last time(implying Zhou was cheating), which triggered some argument between the two sides. Then they discussed the issues of transportation, equipment delivery and reception, as well as how to stock these supplies. ${ }^{206}$

When Stalin learned the news, he was surprised and deeply moved by the Chinese' spirit of sacrifice. On October 14, he sent a cable to Zhou Enlai to express his thanks for the decision made by the Chinese because this sacrificing move saved Stalin out of the dilemma --- he did not want to see North Korea totally crushed by the U.N. forces --- a powerful and stable North Korea would be an ideal buffer zone between the Soviet Union and hostile countries(South Korea, Japan and the United States); nor did he want to send troops or air cover into Korea, which might cause a third world war which he could not afford. After receiving the cable, Zhou sent a 
cable to Stalin with a list of orders for the first group of artillery pieces and peripheral instruments. Two days later, Zhou left Moscow for Beijing. ${ }^{207}$

In one of his articles, Shi Zhe mentioned one important fact that during Zhou's negotiations with Molotov and Stalin, only the quantity of equipment and ammunition was mentioned. As pressed by the urgent situation, nobody mentioned the issue of prices. On the plane back to Beijing, Zhou said that the Chinese accepted the Soviet military assistance only as part of their material support for the Korean War, which meant China need not pay for it. Zhou said he would talk to Stalin at their next meeting in order to reach mutual understanding on the matter. Unfortunately, Zhou never had the chance to talk to Stalin again. As a matter of fact, Stalin never officially mentioned that these military supplies should be paid for by China. This matter was not settled until the early 1960 's when Nikita Khrushchev suddenly asked the Chinese to pay for it in full. ${ }^{208}$

From the strategic angle, Mao believed that there were advantages in sending troops into Korea. His arguments were as follows:

1. Korea was the weak point in America's global strategy. Although the United States was pursuing a strategy of global containment of Communism, its priority was still in Europe where the Soviet Union was its major opponent. The military deployment of the United States in 49 countries made its already inadequate military forces even more thinly spread. The war in Korea would definitely disrupt the United States' strategic priorities and overstretch its defense line. Obviously it could not afford to fight a protracted war in Korea due to its ill-balanced strategy, limited 
manpower, low morale and the reluctance of its allies. ${ }^{209}$

2. The power of the atomic bomb was limited. The limited number of atomic bombs possessed by the United States would not produce a perilous effect on the vast territory of China. Besides, the Soviet Union already had their own atomic bomb. It was no longer monopolized by the United States. In Korea, it would be more difficult to use the atomic weapons since it might hurt its allies on the narrow peninsula. Mao called the atomic bomb a "paper tiger". Still, the CCP put much consideration on its possible consequences -- China was prepared to sacrifice a few million of its people, some coastal cities, the power plants on the Yalu River and the postponement of its economic recovery program. ${ }^{210}$

3. The geographical conditions of Korea were unfavorable to the United States. Korea is a narrow mountainous peninsula, which would greatly limit the mobility of MacArthur's mechanized troops but it would be advantageous to China's infantry troops. Supply would be another serious problem for MacArthur since he had to get most of his supplies from the United States -- more than 10,000 miles away while Chinese troops could be supplied either from Manchuria or directly from the Soviet Union over a much shorter distance. ${ }^{211}$

Even after the order was given to the CPV to enter Korea, Mao still hoped to conclude hostilities with the United States as soon as possible. Some sources show that between October 11 and 13, Mao did not have any sleep for about 60 hours because he had made a very big and very difficult decision in a short time. Mao was aware that if China could not win this war with the United States, the consequence 
would be unthinkable. ${ }^{212}$ Distracted by the sudden change of Stalin's strategy, Mao hesitated even at the final moment. Having asked the first group of the CPV to enter Korea no later than October 17, Mao sent a cable to Peng Dehuai and Gao Gang, asking them to come back to Beijing again for a discussion of the situation. ${ }^{213}$

Finally, Mao was convinced that this confrontation was inevitable and it was better to get troops into Korea before Kim Il Sung retreated to China with his government in exile. ${ }^{214}$ The date for the CPV to enter Korea was postponed from October 17 to October $19,1950 .{ }^{215}$ The reason for this postponement was that the CPV could not complete the preparations according to official Chinese sources. Another possible reason could be that Mao hesitated until the very last moment.

In the meantime, Mao sent an order to Chen Yi, Commander-in-chief of the PLA East China Military Region to move the Ninth Army Corps into Manchuria. Arrangements were made to prevent losses if the United States should declare war upon China, or send its air force to bombard China's big cities and industrial bases and use its navy to attack the coastal areas of China. The few divisions of China's small air force and all the anti-aircraft artillery regiments were deployed around the big coastal cities like Shenyang, Beijing, Tianjin, Shanghai, Nanjing and Guangzhou. Major industrial equipment and strategic materials were removed into remote areas of China. Mao gave instructions to the CCP East China Bureau and Central South Bureau to speed up the land reform and clearance of KMT remnants and four PLA Armies were stationed in Fujian and Guangdong so as to concentrate on a possible landing of Chiang's troops from Taiwan. ${ }^{216}$ Mao especially pointed out: "All the work 
of the Party in East China should be directed under the assumption that the United States and Chiang Kai-shek are going to attack us" and "Guangdong and Guangxi provinces should be regarded as one unit in dealing with Chiang's assaults." ${ }^{217}$ Mao's words clearly defined the priority concern of the Communist Party for their territory.

Facing the crucial fact that the CPV troops would not be protected from air attacks in Korea, Mao and the CCP leadership had to restrict their strategic goals in the first stage of the war. Mao sent a cable to Zhou on October 14, informing him briefly that the CPV troops were going to take a defensive position for the first campaign -- a defensive perimeter would be established from Pyongyang to Wonsan in order to keep bases as the starting points for future offenses. Mao stated that only when all preparations were completed would they launch a counter-offensive. ${ }^{218}$

In the meantime when the Chinese Communists kept sending warnings to the United States not to cross the 38th parallel, President Harry Truman, being skeptical of these warnings, felt it necessary to meet General MacArthur. On October 12, General Marshall informed MacArthur that the President would like to meet him shortly at Honolulu but he was told that "if the situation in Korea is such that you feel you should not absent yourself for the time involved in such a long trip, I am sure the President would be glad to go on to meet you at Wake Island."219 The General replied that he would like to meet the President at Wake Island. ${ }^{220}$

Before this meeting, different views began to appear among the members of the United Nations concerning a peace settlement in Korea. Some Western countries, headed by Great Britain, were opposed to sending U.N. troops into the north and 
preferred a peaceful settlement since "the original objective of the Security Council had been achieved -- the North Korean armies were in full and broken retreat from South Korea."221 MacArthur criticized those people as believing "more could be accomplished by appeasement than by moral resolution"222 and "They seemed to believe that the leaders of Communism would temporize, too." 223 MacArthur took the stand that if the United Nations let North Korea stay behind sanctuary of the 38th parallel, they would prepare another army for the next invasion. ${ }^{224}$

There was a big difference between the first U.N. resolution on Korea and the second one. The first resolution only required the restoration of status quo in Korea while the second resolution was an extension of the first one, which called for its members to take "all appropriate steps" to achieve a unified Korea. Although U.S. troops crossed the parallel on October 7 , the order to advance into North Korea was already issued on September 29 and South Korean troops crossed the parallel on October 1. It was six days before the U.N. Security Council passed the second resolution. This difference in time shows, as confessed by Dean Acheson in his memoirs, that "although introduced by eight other nations, this was another American resolution." 225 This made the Chinese leaders strongly believe that the United Nations was under the control of the United States.

Truman and Acheson had tried to convince the CCP that "the action in Korea was in no sense directed against China" and that "its aims in Korea was purely and simply to repel aggression and help the Koreans to be free, independent and united."226 Simultaneously, it was made plain that "the United States would consider it an act of 
aggression for anyone to join with the North Korean Communists." ${ }^{227}$ The CCP simply regarded the messages from the United States promising not to invade China as a sort of stratagem to gain a respite. Their argument was that they had been fooled by the White House once already(in the example of Formosa) and they could not afford to let it happen again. That is, before the outbreak of the Korean War, both Truman and Acheson openly declared that would not interfere with Chinese affairs and would let Formosa fall into the hands of Chinese Communists. When war broke out in Korea, the White House immediately sent its Seventh Fleet into the Taiwan Strait, which the Chinese Communists regarded as a breach of the "promise" made earlier by the White House not to defend Formosa. They decided to go on with their preparations for an intervention and watched closely the movements of MacArthur's troops $^{228}$.

As one of the top strategists, MacArthur had predicted the possibility of a Chinese intervention when Truman sent the Seventh Fleet into the Taiwan Strait. He warned that the move had "released the two great Red Chinese armies assigned to the coastal defence of central China and made them available for transfer elsewhere."229 These Chinese troops were later reported moving northward into Manchuria. As early as July, 1950, MacArthur had informed the Joint Chiefs of Staff that the enemy forces included Chinese Communists: "This force more and more assumes the aspect of a combination of Soviet leadership with Communist ground elements." ${ }^{130}$ Now it is clear that the forces referred to by MacArthur were Korean soldiers who had served in the PLA and were sent back to Korea with their equipment and weapons before the 
war erupted. However, this shows MacArthur paid close attention to intelligence reports concerning Chinese Army's movements and had knowledge of direct Chinese participation in the conflict.

MacArthur acknowledged that he actually "knew nothing of the purpose"231 of the coming meeting with the President on Oct 15, 1950. His knowledge about the President was that the latter knew little of the Oriental nations but had "a strong combination of distorted history and vague hopes that somehow, some way, we could do something to help those struggling against Communism." 232

Dean Acheson privately regarded this meeting as "futile and demeaning to the office of the President" ${ }^{233}$ because "it was the only occasion in which he felt Truman failed to maintain the authority and prestige of his office." ${ }^{234}$ Dean Acheson did not go to Wake Island with the President because he "wanted no part of it, and saw no good coming from it". ${ }^{235}$

The President explained his motives as "I went because I want to see and talk to General MacArthur. The best way to see him and talk to him is to meet him." ${ }^{236}$ But General Willoughby thought the President aimed to share MacArthur's military achievements at Inchon and make use of it in the coming presidential election. ${ }^{237}$

At Wake Island, Truman talked with MacArthur on various topics -- the ending of war in Korea; the Japanese peace treaty; the post-war reconstruction of Korea and the prospects for Russian and Chinese intervention as well as the possibility of a war with China. Although the issue of Russian or Chinese entry into the war "was brought up almost casually"238 by the President, it was obviously one of his major concerns. 
As early as October 5, the President had got intelligence reports that "18 Red divisions [were] along the Yalu, while an over-all total of 38 divisions was carried in Manchuria."239 At that time in areas near the Yalu River there were only 4 American divisions plus 4 South Korean divisions. ${ }^{240}$ Still, MacArthur told Truman that the chance for a Chinese intervention was "very little" by pointing out that the Chinese had no air cover and they could at most move 50-60,000 men across the Yalu River and he assured the President that the war was going to be over by Thanksgiving and that there would be the "greatest slaughter" if the Chinese dared to challenge his troops. ${ }^{241}$ The President seemed to be satisfied with the General's explanation and they switched on to other topics. The fact is it was almost impossible to prove how many men the Chinese could actually get across the Yalu River since Truman ordered that American planes stay 20 miles away from the Yalu River, which forbade "hot pursuit" into the Chinese side of the river. ${ }^{242}$

The real opinion of the general lies in his own words: "Had they interfered in the first or second months it would have been decisive" and that the U.N. forces were "no longer fearful of their intervention. ${ }^{243}$ The general thought that his army could defeat any challenge from the Chinese: "my own military estimate was that with our largely unopposed air forces, with their potential capable of destroying, at will, bases of attack and lines of supply north as well as south of the Yalu, no Chinese military commander would hazard the commitment of large forces upon the devastated Korean peninsula. The risk of their utter destruction through lack of supply would be too great." ${ }^{244}$ Strategically, there was nothing wrong with MacArthur's theory. But both 
Truman and MacArthur neglected one thing -- the Chinese Communists, like other communists in the world, always gave first priority to politics in conducting a war. Secondly, the Chinese Communists did not quite understand the working procedure of the American political system. They did not understand the checks and balances of western democracy, naively believing that the President and the General were working for the same goal. As a result, when the President proclaimed, after the long trip, that "I have just returned from Wake Island where I had a very satisfactory conference with General Douglas MacArthur," ${ }^{245}$ the CCP regarded this as an open denial to their earlier warnings that the United States was determined to enlarge the war into North Korea and perhaps into Manchuria as well. ${ }^{246}$

The CCP was more convinced that Manchuria was the U.N. forces' next target when MacArthur returned to Tokyo on October 17 and ordered the 8th Army and 10th Army to advance directly to the Yalu River instead of the original plan to use the South Korean troops as the spear. ${ }^{247}$ Since the U.N. troops were pushing towards the Yalu river very rapidly and Pyongyang was going to fall in a day or two, Mao and Peng made the decision that the CPV had better get ready to cross the Yalu River on October $17 .{ }^{248}$ On the same day, Mao cabled to the CPV headquarters in Shenyang, asking them to cross the River on october $19 .{ }^{249}$ Peng Dehuai and Gao Gang flew to Beijing at once. On October 18 , the official order was given to the CPV to enter Korea: "... decision has been made that the CPV four armies and three artillery divisions will enter North Korea for combat according to the original plan.... the crossing will start early every evening and end every early morning in order to keep it 
a secret.... The first night(19th) at least two or three divisions must be transferred into Korea. The second night same or more divisions will be sent into Korea."250

Top Chinese leaders met again on October 18 in Beijing to discuss details. Zhou presented a report about military assistance from the Soviet Union. He said Stalin would send equipment and ammunition the CPV needed and the Soviet air force would not enter the war for sure but would defend Chinese territory. ${ }^{251}$ It was likely that Zhou Enlai had exchanged with Stalin about the priority concern of the CCP for their security.

On October 19, 1950, the CPV crossed the Yalu River. On October 20, Peng Dehuai met Kim Il Sung and Pak Hon Yong. Peng discussed with Kim three likely prospects of the Chinese involvement: "(1) We will be able to hold our ground by eliminating the enemy, thus leading to a reasonable solution of the Korean problem. (2) We will be able to hold our ground, but cannot eliminate the enemy, and the war will enter a stalemate. (3) We fail to hold our ground, and are driven back [to China]. we will surely try our best to achieve the first." ${ }^{252}$ Peng then told Kim Il Sung that the first group of the CPV that had crossed the Yalu was 260,000 in total. The CPV had a reserve force of 80,000 men in Manchuria which would be transferred into Korea soon. In order to prevent any unfavorable situation from happening, the CCP Military Committee also mobilized another 20 divisions as the second and third echelons. The total number of men of the CPV would reach 600,000 . Peng also told Kim that the key point in the Chinese involvement was to achieve an impartial and reasonable solution. In the meanwhile, China should be prepared for the United States to declare 
war on her or bombard Manchuria and China's industrial bases. ${ }^{253}$ In the first stage of the Chinese intervention, their goal was to drive the U.S. troops into the sea and reach a "reasonable solution". ${ }^{254}$ By "a reasonable solution" the CCP meant the withdrawal of the U.N. forces back to the 38th parallel and the restoration of North Korea Territory

On the same day of the Chinese entry into Korea, Pyongyang was captured by the U.N. troops. At some points U.N. troops(South Koreans) advanced as far as within 30-40 miles of the Chinese-Korean border. Facing this new situation, the CPV headquarters decided to change their original defensive combat plan since the rapid advance of the U.N. forces made it impossible for the CPV to establish a defensive perimeter. Peng cabled to Beijing, suggesting they wipe out the enemy troops in the form of a mobile war. This plan was immediately approved by Mao Zedong. ${ }^{255}$ Mao instructed Peng in a cable: "The problem now is how to complete, in tactical sense, preparations for the campaign within a few days so that we can start the combat in a few days; you should not try to deploy the defense for a period and then start the offensive." 256

This readjustment of strategy on the Chinese side proved to be a great success. On October 25, the 118th Division under the 40th Army of the CPV initiated the first surprise attack upon South Korean troops in the Unsan area. In twelve days, South Korean troops were forced to retreat from the Yalu to the Chongchun River. The Chinese statistics showed that about 15,000 south Korean soldiers were killed or captured in this campaign. ${ }^{257}$ 
Nevertheless, this setback did not serve as a serious warning to General Macarthur that the Chinese were intervening in a large scale. The general, like other U.S. leaders, underestimated the capability and determination of the Chinese. In early November, he scheduled the start of a new "end the war" offensive campaign. Actually, MacArthur did get reliable information about the Chinese army's movements in North Korea. ${ }^{258}$

This suggests, as has been discussed earlier, that MacArthur welcomed the Chinese encounter. He aimed to fight a general war in Asia so as to check the Communist expansion and to prove his theory that Asia was the major theater to deter Communism.

On October 23, Mao again sent a cable to Peng Dehuai, instructing Peng to take advantage of the U.N. forces' ignorance of the CPV presence in the north so as to wipe out two or more South Korean divisions first. Even at this time, Mao still hoped what the CCP was doing could bring the United States to negotiations for a peaceful solution. Mao's argument was if the CPV could wipe out a few "puppet"(referring to South Korean troops) divisions and win the first victory, the situation would turn to the favor of China and North Korea, which would possibly force the United States to seek diplomatic means for negotiations with China. ${ }^{259}$

The CPV headquarters followed the traditional communist war strategy -purposely showing Chinese weakness, increasing the arrogance of the enemy and letting them run wild and luring them deep into our areas. ${ }^{260}$ In light of this strategy, Peng Dehuai ordered all his troops to retreat for about 30 kilometers so as to occupy 
favorable positions, and to wait for the best opportunity to attack the enemy. ${ }^{261}$

On November 9, Mao cabled Peng, approving the CPV' plan of preparations of the second campaign. In the cable, Mao suggested: " We are trying to fight one or two battles from now to early December in order to eliminate seven or eight enemy regiments on both the eastern and western fronts and push the front line up to the railway areas between Pyongyang and Wonsan. If we can manage to do so, the basic victory of the war is ours." ${ }^{262}$ Mao made this plan as he realized that it was hard to drive the United States into the sea as the CCP had hoped because of the limits of China's military strength and the special geography of the long Korean peninsula which is open to assaults from the sea like the Inchon Landing.

On November 25, the CPV troops started their counter-offensive on both the eastern and western fronts. It forced the U.N. forces to begin "the most infamous retreat in American military history". ${ }^{263}$ On December 5, the CPV troops recaptured Pyongyang. By the end of 1950, the CPV troops had regained nearly all the lost territory for North Korea.

This setback finally made MacArthur realize that he was facing "an entirely new war". However, he did not show any intention to abandon his aggressive strategy. Instead, he suggested more aggressive actions in North Korea and even in Manchuria. His aggressiveness eventually led to a split between him and the President and was the major reason in his dismissal by the President. ${ }^{264}$

From December 311950 to May 21, 1951, the CPV launched the Third, Fourth and Fifth campaigns which pushed back the U.N. forces south of the 38th parallel and, 
stabilized the CPV's front line at the 38th parallel. ${ }^{265}$ From this time on the war became small-scale battles and both the Chinese side and the United Nations side began to show the intention for a solution through negotiations.

On June 23, 1951, Jacob Malik, the Soviet Representative at the United Nations, with the approval of both Chinese and North Koreans, formally called for a ceasefire. The CCP immediately endorsed Malik's initiative. ${ }^{266}$ On July 10, 1951, Chinese and North Korea representatives and the U.N. delegates met for the first time at Kaesong -negotiations to end the conflict started and took two years for the two sides to reach an acceptable agreement. On July 27,1953 , the armistice was signed by both sides and it went into effect 12 hours later, thus ending the largest bloody conflict between the two camps since the Second World War and the start of the Cold War. ${ }^{267}$

In the research of the Korean War, many scholars, both Chinese and American, agree that it was the concern of national security of the CCP that brought China into the conflict. This is of course the bottom line of the CCP's decision to enter the war. In addition, the Sino-Soviet Alliance committed China to some responsibility based on Communist internationalism to send help to North Korea when necessary.

The Korean War was an occasion to test the strength and viability of the SinoSoviet Alliance. In this conflict, Stalin was totally convinced of the Chinese Communists' strength and determination. On the other hand, the Chinese Communists were shocked to see Stalin's "betrayal" in the refusal of the Soviet to provide air cover which resulted in much greater Chinese casualties and naturally left a deep crack in the relations between the two Communist nations. 
Before this intervention the CCP tried every means to warn the United States(the leading state in the United Nations forces in Korea) so as to avoid a direct military conflict with the United States since they knew well their economic potential did not allow them to risk a general war. To the CCP's disappointment, the White House policy makers were obviously influenced and attempted and gambled on a very likely unified pro-American Korea. 


\section{CONCLUSION}

From the above analysis, it is quite clear the reason why the CCP chose to make this decision was primarily security concerns. To be more specific, what the CCP really feared was the coming-back of Chiang Kai-shek and the loss of their regime as shown in the CCP's communications with the Soviet Union and their warnings to the United States. Fearing a potential menace from the United States and believing that a military conflict between the United States and China was inevitable, the Chinese Communist leaders thought it might be better for them to choose time and place for the war. The CCP had reasons to take the risk. When American troops, following South Korean troops, finally crossed the 38th parallel (which had been regarded by the CCP as the final limit) and advanced in the direction of the Yalu River, the Chinese troops went across the Yalu River and joined the fighting. Thus the Korean War became a conflict principally between America and China. Although there were some changes in the Chinese Communists' aims in joining this war, the eventual aim of China was to deter the enemy from further adventures and to achieve a 'just" peace in Korea by which they meant the status quo ante bellum. The CCP have been regarding this war as a total victory over the U.S. Imperialist "Paper Tiger" because they successfully pushed the U.N. forces back behind the 38th parallel, saved their communist neighbor from being crashed and secured their Manchurian border. In 
retrospect, the conflict between China and the United States could have been avoided if the CCP and the White House policy makers had communicated with each other better and understood each other's intentions better. 


\section{NOTE}

1. Quoted from Allen S. Whiting, China Crosses The Yalu (New York, 1960), 151 .

2. Liu Suinian and Wu Gungan, China's Socialist Economy An History 1949-1984 (Beijing, 1986), 16.

3. Li Shixin. "Chiang Chin-kuo And The Monetary Reform in Shanghai", Gao Yi ed. Untold Stories of History (Gansu, China, 1988), 384386.

4. Frank H.H. King. A Concise Economic History of Modern China(Praeger, 1967), 165-167.

5. Ygael Gluckstein. Mao's China (Boston, 1957), 43.

6. U.S. CIA. PRC Handbook of Economic Indicators, 1-3.

7. Liu Suinian. China's Socialist Economy An Outline History 1949-1984, 16.

8. Ygael Gluckstein. Mao's China, 43.

9. China Handbook Editorial Committee. Economy, 1-3.

10. Ygael Gluckstein, Mao's China, 20.

11. Liu Suinian. China's Socialist Economy An Outline History 1949-1984, 43-46.

12. Ibid., 43-46.

13. Jan Prybyla. The Chinese Economy (South Carolina, 1978), 153-154.

14. Ygael Gluckstein, 44.

15. Solomon Adler. The Chinese Economy (New York, 1957), 10.

16. Ibid., 5 .

17. Xie Lifu. Untold Story of the Korean War,(World of Knowledge Press, 1993) 162-163.

18. Liu Suinian, 115 . 
19. Mao Zedong. "Instructions On The Army's Participation In Production And Construction Work In 1950": Miscellany Of Mao Zedong Thought 1949-1968 Part I: JPRS 61269-1 Feb 20, 1974, 2.

20. Jiang Bao-qi. Study of China's Defense Economy Development Strategy (Beijing: National defense Press, 1990), 13.

21. See Melvin Gurtov. China Under Threat (Baltimore, 1980), 41.

22. Mao Zedong. Selected Works by Mao Zedong (Beijing, 1969), VOL IV. 417.

23. See Chen Jian, 21: He Di, "The Last Campaign To Unify China: The CCP's Unmaterialized Plan To Liberate Taiwan, 1949-1950", Chinese Historians, VOL. V. No.1, 7-8.

24. World Journal, Oct 20, 1992, 20.

25. See Robert R. Simmons. The Strained Alliance (New York, 1975), 69: People's Daily Oct 8, 1949

26. See Mao Zedong. "Farewell, Leighton Stuart", Selected Works, VOL 4., 434. In this article, Mao noted: "There were U.S. naval bases in Tsingtao, Shanghai and Taiwan. U.S. troops were stationed in Peiping(Beijing), Tientsin, Tangshan, Chinwangtao, Tsingtao, Shanghai and Nanjing. The U.S. air force controlled all of China's air space and took aerial photographs of all China's

strategic areas for military maps. At the town of Anping near Peiping, at Chiutai near Changchun, at Tangshan and in the Eastern Shantung Peninsula, U.S. troops and other military personnel clashed with the People's Liberation Army and on several occasions were captured. Chennault's air fleet took an extensive part in the civil war. Besides transporting troops for Chiang Kai-shek, the U.S. air force bombed and sank the cruiser Chungking, which had mutinied against the Kuomingtang." Mao concluded that "all these were acts of direct participation in the war, although they fell short of an open declaration of war and were not large in scale, and although the principal method of U.S. aggression was the large supply of money, munitions and advisors to help Chiang kai-shek fight in the civil war."

27. Mao Zedong, Quotations From Chairman Mao Zedong (New York, 1969), 13.

28. Raymond L. Garthoff, Sino-Soviet Military Relations (New York, 1966), 83.

29. Chen Jian, "The Sino-Soviet Alliance and China's Entry into the Korean War", 6. in The Woodrow Wilson Center, Cold War International History Project. Washington, D.C. 1992.

30. Ygael Gluckstein, Mao's China (Boston, 1957), 394. 
31. Ibid.

32. Ibid., 396.

33. Chen Jian, "The Sino-Soviet Alliance and China's Entry Into the Korean War", 8-9.

34. Ibid., 7.

35. Doak Barnett, Communist China and Asia (New York, 1961), 63.

36. Liu Jiecheng, Mao Zedong and Stalin(Beijing, 1993), 548-549.

37. Shi Zhe, "Random Reflections of Comrade Liu Shaoqi", Geminghuiyilu, supplementary issue, No.1, October, 1983, 110-111.

38. Ibid.

39. Chen Jian, "The Sino-Soviet Alliance and China's Entry into the Korean War", 14.

40. Ibid.

41. Mao Zedong to the CCP Central Committee, January 3, 1950, Mao Zedong wengao, I, 213.

42. Liu Jiecheng, Mao Zedong and Stalin, 18-19.

43. Ibid., 16.

44. Ibid., 17.

45. Chen Jian, "The Sino-Soviet Alliance and China's Entry into the Korean War", 18.

46. Beijing Review, November 21, 1983, 18.

47. Ibid.

48. Winberg Chai, The Foreign Relations of the People's Republic of China (New York, 1971), 128.

49. Aitchen K. Wu, China and the Soviet Union (New York, 1950), 333.

50. Ibid., 334. 
51. Chen Jian, "The Sino-soviet Alliance and China's Entry into the Korean War", 18-20.

52. Mao Zedong, "Speech at the Tenth Plenum of the Eighth Central Committee": Stuart Schram ed., Chairman Mao Talks to the People: Talks and Letters: 19561971 (New York, 1966), 83.

53. Winberg Chai, The Foreign Relations of the PRC, 128.

54. Wang Gungwu, China and the World since 1949 (New York, 1977), 36.

55. N.S. Khrushchev, Klurushchev Remembers: The Glasnost Tapes, trans and ed. by Jettold L. Schecter with Vyacheslav V.(Luchkov, 1990), 143.

56. Ibid.

57. Ibid.

58. Ibid.

59. Ibid.

60. Nie Rongzhen, Nie Rongzhen Huiyilu(Beijing, 1984), 3: 744.

61. Melvyn P. Leffler, "The American Conception of National Security and the Beginnings of the Cold War, 1945-1948,"American Historical Review 89 (1984): 351-58, 365-66.

62. New York Times, March 2 1946; Harbutt, Iron Curtain, 179-96.

63. Gaddis Smith, Dean Acheson The American Secretaries of State and Their Diplomacy (New York, 1972), 117.

64. Ibid.

65. John Leighton Stuart, Fifty Years in China (New York, 1954), 270.

66. Mao Zedong, Selected Works of Mao Zedong (Beijing, 1969), 425.

67. Ibid., 429 .

68. Ibid., 433 .

69. Department of State, Foreign Relations of the United States, 1950, VOL VII., 180.

70. Harry Truman, Memoirs,(New York, 1956), VOL II., 91. 
71. Department of State, Foreign Relations of the United States, 1949, VOL IX., 290-291.

72. Ibid., 292.

73. Department of State, Department of State Bulletin, VOL XXII. 1950, NO 550, 79.

74. Department of State, Foreign Relations of the United States, 1949, VOL IX., 281.

75. Ibid., 295-296.

76. Gaddis Smith, Dean Acheson The American Secretaries of State and Their Diplomacy, 122.

77. Department of State, Foreign Relations of the United States, 1949, VOL IX., 157.

78. Ibid.

79. Department of State, Document of Foreign Relations, 539.

80. Ibid., 429.

81. Ibid., 431 .

82. Bruce Cumings, The Origins Of The Korean War(Princeton, 1990), VOL II, 409.

83. Ibid., 410 .

84. Charles M. Dobbs, The Unwanted Symbol: American Foreign Policy, The Cold War, And Korea, 1945-1950 (Kent, ohio, 1981), 161.

85. Dean Acheson, as cited in Bruce Cumings, The Origins Of The Korean War (Princeton, New Jersey: 1983), 408.

86. Ibid.

87. Chai Chengwen and Zhao Jungtian, Panmunjom Negotiations (Beijing, 1992),23.

88. Ibid.

89. Gao Ge,ed., Untold Stories in History (Gansu, China, 1988), II., 186. 
90. Gaddis Smith, Dean Acheson American Secretaries of State and Their Diplomacy, 185-186.

91. Chae-Jin Lee and Hideo Sato, 12.

92. Harry Truman, Memoirs, 335.

93. Glenn Paige, 1950: Truman's Decision the United States Enters the Korean War (New York, 1970), 64-65.

94. Harry Truman, Memoirs, 331-334.

95. Ibid., 334 .

96. Stephen E. Ambrose, Rise to Globalism (New York, 1971), 119.

97. Roderick MacFarquhar, Sino-American Relations, 1949-1971 (New York, 1972), 83

98. Ibid.

99. Xie Lifu, Reports of the Korean War(Beijing, 1993),134.

100. People's Daily, June 29, 1950, 1.

101. Gao Ge, Untold Stories in History, 4.

102. Ibid., 136.

103. Ibid.

104. Ibid.

105. Department of State, Foreign Relations of the United States, 1950, VOL VII., 488.

106. Ibid., 768 .

107. Douglas MacArthur, A Soldier Speaks (New York, 1965), 244.

108. Ibid.

109. Ibid., 251 .

110. Ye Yumeng, Facts Behind China's Entry into the Korean War (Jinan, China, 1990), 4. 
111. Douglas MacArthur, Duty, Honor, Country(New York, 1965), 144.

112. Ibid.

113. Ibid.

114. Ye Yumeng, Facts Belind Clina's Entry into the Korean War, 4.

115. Xie Lifu, Reports of the Korean War, 139.

116. Bo Yibo, Ruogan zhongda jueche yu shijian de huigu (Beijing, 1991) VOL I., 43 .

117. Mao Zedong and the CCP Central Committee to Gao Gang, August 5, 1950, Mao Zedong Wengao, VOL I, 454. As cited in Chen Jian, 24 .

118. People's Daily, August 7, 1950, 1.

119. Xie Lifu, Reports of the Korean War, 140.

120. Chai Chengwen, Panmunjom Negotiations, 58.

121. Melvin Gurtov and Hwang Byong-Moo, China Under Threat (Baltimore, 1980), 51.

122. Chen Jian, "The Sino-Soviet Alliance and China's Entry into the Korean War", 25 .

123. Ibid.

124. Ye Yumeng, Facts of China's Entry into the Korean War, 38-40.

125. Nie Rongzhen, Nie Rongzhen Huiyilu(Beijing, 1984), VOL III, 721-722. As cited in Hao Yufan, 94.

126. Xie Lifu, Reports of the Korean War, 141.

127. Ibid.

128. Chai Chengwen, Panmunjom Negotiations, 58-59.

129. Ibid., 77.

130. Melvin Gurtov and Hwang Byong-Moo, 51.

131. Chai Chengwen and Zhao Yongtian, Panmunjom Negotiations (Beijing, 1992), 69. 
132. Ibid., 70 .

133. Ibid., 70 .

134. Ibid., 70.

135. Ibid., 65 .

136. Ibid., 64-54.

137. Ibid.

138. Ibid.

139. Douglas MacArthur, Reminiscence (New York, 1964), 357.

140. Xie Lifu, Reports Of the Korean War (Beijing, 1993), 141.

141. Ibid.

142. Chai Chengwen, Panmunjom Negotiations, 66.

143. Ibid.

144. Edmund Traverso, K.M. Panikkar in Two Chinas (Menlo Park, California, 1970), 107-108.

145. Ibid.

146. Ibid.

147. Chai Chengwen, Panmunjom Negotiations, 70.

148. Department of State, Foreign Relations of the United States, 1950, VOL VII., 826.

149. Douglas MacArthur, A Soldier Speaks (New York, 1965), 225-226.

150. Chai Chengwen, Panmunjom Negotiations, 71.

151. Ibid.

152. Ye Yumeng, Facts Behind China's Entry into the Korean War (Jinan, China, 1990), 41-43.

153. Ibid., 45 . 
154. Ibid., 46.

155. The New York Times International, Wednesday, Feb 26, 1992, A4.

156. Ibid.

157. Ibid.

158. Ibid.

159. Xie Lifu, Reports of the Korean War, 160.

160. Ibid.

161. Chai Chengwen, Panmunjom Negotiations, 72.

162. Ibid.

163. Edmund Traverso, K.M. Panikkar in Two Chinas, 109-111.

164. Harry Truman, Memoirs (New York, 1956), 362.

165. Ibid.

166. Chai Chengwen, Panmunjom Negotiations, 72.

167. Zhou Enlai, Selected Works of Zhou Enlai (Beijing, 1992), 51. As cited in Hao Yufan, 103.

168. Ibid.

169. Ye Yumeng, Facts Behind China's Entry into the Korean War, 39.

170. Yao Xu, From Yalu River to Panmunjon (Beijing, People's Press, 1985), 20.

171. Ibid.

172. Ye Yumeng, Facts Behind China's Entry into the Korean War, 39-40.

173. Hao Yufan and Zhai Zhihai, "China's Decision to Enter the Korean War": China Quarterly, March, 1990, NO.121, 105.

174. Ye Yumeng, Facts Behind China's Entry into the Korean War, 67.

175. Jonathan D. Pollack, "The Korean War and Sino-American Relations": Harry Harding \& Yuan Ming, ed. Sino-american Relations, 19451955 (A Scholarly Resources Imprint Wilmington, Delaware, 1989), 219. 
176. Ibid.

177. Peng Dehuai, Peng Dehuai zhishu (Beijing, 1992), 258.

178. Ibid.

179. Xie Lifu, Reports of the Korean War, 194.

180. Chai Chengwen, Panmunjom Negotiations, 33.

181. Mao Zedong, Selected Works of Chairman Mao on Military Affairs(Internal circulated), 328.

182. Zhang Xi, Before and After Peng Deluai's Appointment to Command the CPV in Korea, 123-125. As cited in Chen Jian, "The Sino-Soviet Alliance and China's Entry into the Korean War", 27.

183. Ibid.

184. Peng Dehuai, Peng Dehuai Zhishu, 257.

185. Ibid.

186. Ibid., 258.

187. Ibid.

188. Chai Chengwen, Panmunjom Negotiations, 73.

189. Xie Lifu, Reports of the Korean War, 169-170.

190. Ibid.

191. Chai Chengwen, Panmunjom Negotiations, 74.

192. Xie Lifu, Reports of the Korean War, 178.

193. Ibid., 179.

194. Liu Jiecheng, Mao Zedong and Stalin (Beijing, 1993), 562.

195. Ibid.

196. Shi Zhe, "Behind the War: The Interview Between Zhou Enlai and Stalin", Junshi shilin (Military History Magazine), No 3, 1992.

197. Ibid. 
198. Zhang Xi, 147-148. See also Gao Ge, Facts Beluind Chinas Entry into the Korean War, 90-92.

199. Xie Lifu, Reports of the Korean War, 180-181.

200. Ibid.

201. Ibid., 177.

202. Ibid.

203. Zhang $\mathrm{Xi}, 150$.

204. The CCP Archives Department, The Road the Republic Takes (Collection of Important CCP documents)(Beijing, 1991), 259.

205. Ibid.

206. Shi Zhe, "Behind the War: The Interview Between Stalin and Zhou Enlai", in Junshi shilin (Chinese military history), No 3, 1992, 14.

207. Ibid.

208. Ibid.

209. CCP Central Committee, "Instruction on Current Issue Propaganda", October 26, 1950. As cited in Hao Yufan and Zhai Zhihai, "China's Decision to Enter the Korean War": China Quarterly, March, 1990, No.121, 96.

210. Ibid.

211. Ibid.

212. Hao Yufan and Zhai Zhihai, "China's Decision to Enter the Korean War", China Quarterly, March, 1990, NO.121, 111.

213. Mao Zedong, Mao Zedong Wengao I: 568. As cited in Chen Jian, "China's Changing Aims in the Korean War": The Journal American-East Asian Relations, Spring, 1992, VOL.1, NO.1, 23.

214. Hao Yufan and Zhai Zhihai, "China's Decision to Enter the Korean War", 111.

215. Nie Rongzhen, Memoirs of Nie Rongzhen (Beijing, 1986), 737.

216. Xie Lifu, Reports of the Korean War (Beijing, 1993),182.

217. Ibid. 
218. Mao to Zhou, October 14, 1950, Mao zedong wengao, 1: 558-559.

219. Douglas MacArthur, Reminiscences (New York, 1964), 360.

220. Ibid.

221. Dean Acheson, The Pattern of Responsibility (Cambridge, Massachusetts, 1951), 263.

222. Douglas MacArthur, Reminiscences, 357.

223. Dean Acheson, The Pattern of Responsibility, 263.

224. Douglas MacArthur, Reminiscences,358.

225. Gaddis Smith, Dean Acheson, American Secretaries of State and Their Diplomacy (New York, 1972), 209.

226. Dean Acheson, The Pattern of Responsibility, 263.

227. Ibid.

228. Chai Chengwen and Zhao Yongtian, Panmunjom Negotiations Beijing, 1992), 64-65.

229. Douglas MacArthur, Reminiscences, 359.

230. General Douglas MacArthur to Joint Chief of Staff, 9 July 1950, CX57481, File 795.00, DS. As cited in Barton J. Bernstein, "New Light on the Korean War", The International History Review III, 2, April 1981.

231. Douglas MacArthur, Reminiscences, 360.

232. Ibid., 361 .

233. Gaddis Smith, Dean Acheson, American Secretaries of State and Their Diplomacy, 210.

234. Ibid.

235. Dean Acheson, Present at the Creation(New York, 1969), 456.

236. Harry Truman, Memoirs, 367.

237. Charles A. Willoughby and John Chamberlain, MacArthur 1941-1951 (New York, 1954),382. 
238. Ibid., 383 .

239. Ibid.

240. Ibid.

241. Ibid.

242. Gaddis Smith, Dean Acheson, American Secretaries of States and Their Diplomacy, 214.

243. Richard H. Rovere, The General and the President and the Future of American Foreign Policy (New York, 1951), 132.

244. Douglas MacArthur, Reminiscences, 362.

245. Harry Truman, Memoirs, 367.

246. Chai Chengwen and Zhao Yongtian, Panmunjom Negotiations, 76-81.

247. Ibid.

248. Liu Jiecheng, Mao Zedong and Stalin (Beijing, 1993), 570.

249. Ibid.

250. Ibid., 570 .

251. Chen Jian, "China's Changing Aims During the Korean War" in The Journal of American-East Asian Relations, Spring, 1992, VOL 1, NO 1, 23.

252. Chai Chengwen and Zhao Yongtian, Panmunjom Negotiations, 83-87.

253. Ibid.

254. Ibid.

255. Xie Lifu, Reports of the Korean War, 199-200.

256. Mao Zedong, Mao Zedong junshi wenxuan (Selected Military Works of Mao Zedong) (Beijing, 1981), 652 .

257. Peng Dehuai, Peng Dehuai zhishu (Memoirs of Peng Dehuai)(Beijing, 1991), 259.

258. William W. Stueck, Jr. The Road to Confrontation: American Policy toward China and Korea, 1947-1950(Chapel Hill, N.C., 1981), 241-246. 
259. Xie Lifu, Reports of the Korean War, 204.

260. Peng Dehuai, Peng Dehuai zhis/m, 259-260.

261. Ibid.

262. Liu Jiecheng, Mao Zedong and Stalin, 573.

263. Jonathan Pollack, "The Korean War and Sino-American Relations," in Harry Harding and Yuan Ming, eds., Sino-American Relations, 1945-1955: A .bint Reassessment of a Critical Decade (Wilmington, Del., 1989), 224. As cited in Chen Jian (2), 26.

264. In an announcement to fire MacArthur, Harry Truman stated that only limited military actions should be taken in Korea and that General MacArthur was intending to fight a general war that might cause a third world war. As the president he could not tolerate this from happening. "Korea, the Forgotten War" TV Documentary Film Program on the Discovery Channel (Channel 17, Columbia Cable Company)April 24, 1994.

265. Chai Chengwen and Zhao Yongtian, Panmunjom Negotiations, 103-112.

266. Renmin ribao, June 25, 1951.

267. Chai Chengwen and Zhao Yongtian, Panmunjom Negotiations, 273-276. 


\section{BIBLIOGRAPHY}

\section{PRIMARY SOURCES}

Acheson, Dean. Power And Diplomacy. Cambridge, massachusetts:

Harvard University Press, 1959.

Acheson, Dean. Present At The Creation My Years In The State Department. New York: W.W. Norton \& Company. Inc., 1969.

Bo Yibo. Ruegan zhongda jueche yu shijian de huigu (Recalling Some Important Decisions and Incidents). Beijing: The CCP party School Press, 1991.

Bouc Alain. Mao Tse-tung: A Guide To His Thought. New York: St. Martin's Press, 1977.

The CCP Archives. The Road The Republic Took 1949-1952. Beijing: The CCP Archives Press, 1991.

Chai, Chengwen and Zhao Yongtian. Panmunjom Negotiations. Beijing: PLA Press, 1992.

Chai, Winberg. The Foreign Relations Of PRC. New York: Capricorn Books, 1972.

Dennett, Raymond \& Robert K. Turner. (ed). Documents Of American Foreign Relations. Princeton: Princeton University Press For World peace Foundation.

Devilers, Philippe. Mao. New York: Schoken Books, 1969.

Gao, Ge (ed). Historical Facts Behind The Screen. Gansu, China: Gansu people's Press, 1988.

Howard, Roger. Mao Tse-tung And The Chinese People. New York: Monthly Review Press, 1977.

Koln, Artech. Mao. New Jersey: Seton Hall University Press, 1972.

Liu, Jiecheng. Mao Zedong And Stalin. Beijing: The CCP Party School Press, 1993. 
1965.

MacArthur, Douglas. Reminiscences General Of The Army. New York: McGraw-Hill Book Company, 1964.

MacArthur, Douglas. A Soldier Speaks Public Papers And Speeches Of General Of The Army. New York: Frederick A. Praeger, Publishers, 1965.

Mao, Tse-tung. Military Writings Of Mao Tse-tung. Beijing: Foreign Languages Press, 1967.

Mao, Tse-tung. Quotations From Chairman Mao Tse-tung. United States: Bantom Books, Inc., 1967.

Mclellan, Davis S. And David C. Acheson. Among Friends Personal Letters Of Dean Acheson. New York: Dodd, Mead \& Company, 1980.

Payne, Robert. Mao Tse-tung. New York: Weybright And Talley, 1969.

Peng, Dehuai. Peng Deluai zhishu (Autobiography of Peng). Beijing: People's Press, 1991.

Schram, Stuart R. The Political Thought Of Mao Tse-tung. New York: Frederick A. Praeger, Publishers, 1963.

Schram, Stuart R. Mao Tse-tung. New York: Simon And Schuster, 1966.

Snow, Edgar. Red Star Over China New York: Grove Press Inc., 1961.

Terrill, Ross. Mao A Biography. New York: Harper \& Row, Publishers, 1980.

Truman, Harry S. Memoirs By hary S. Truman. Garden City, N.Y.: Doubleday \& Company, Inc., 1956.

Wilson, Dick. Mao The People's Emperor: London: Hutchinson \& Co., 1979.

Xie, Lifu. Reports Of The Korean War: Beijing: World Knowledge Press, 1993.

Yin, Helen and Yi-chang Yin. Economic Statistics Of Mainland China. Cambridge, Massachusetts: Harvard University Press, 1960. 


\section{SECONDARY SOURCES}

Ambrose, Stephen. Rise To Globalism. New York: Viking Penguin Inc., 1971.

Barnett, A. Doak. Communist China And Asia. New York: Vintage Books, 1960.

Bemis, Samuel Flagg. A Diplomatic History Of The United States. New York: Holt, Rinehart And Winston, Inc., 1965.

Bundy, McGeorge. (ed) The Pattem Of Responsibility. Cambridge, massachusetts: The Riverside Press, 1952.

Cochran, Bert. Hany Truman And The Crisis Piesidency. New York: Funk \& Wagnalls, 1973.

Cumings, Bruce. The Origins Of The Korean War. Vol. II. Princeton, New Jersey: Princeton University Press, 1990.

Dobbs, Charles M.. The Unwanted Symbol American Foreign Policy, the Cold War, And Korea, 1945-1950. Kent, Ohio: The Kent State University Press, 1981.

Ferrell, Robert H. Harry S. Truman And The Modem American. Boston: Little, Brown And Company, 1983.

Ferrell, Robert H. (ed). Autobiography Of Hary S. Truman. Boulder, Colorado: Colorado Associated University Press, 1980.

Foot, Rosemary. The Wrong War American Policy And The Dimensions Of The Korean Conflict, 1950-1953. Ithca, . London: Cornell university Press, 1985.

Garver, John W. Foreign Relations Of The People's Republic Of China New Jersey: Prentice Hall, 1993.

Gardner, Llod C. The Korean War: New York: Quadrangle Books, 1972.

Garthoff, Raymond L. Sino-Soviet Military Relations. New York: Frederick Praeger, Publishers, 1966.

Gluckstein, Ygael. Mao's China. Boston: The Beacon Press, 1957.

Gurley, John G. China's Economy And The Maoist Strategy. New York: Monthly Review Press, 1976. 
Guttman, Allen. Korea And The Theory Of Limited War. Boston: D.C. Heath And Company, 1967.

Hoyt, Edwin P. The Day The Chinese Attacked --- Korea, 1950. New York: McGrawHall Publishing Company, 1990.

Hsu, Immanuel C.Y. The Rise Of Modem China London: Oxford University Press, 1975.

The International Studies Group Of The Brooking Institution Washington, D.C. Major Problems Of United States Foreign Policy. Wisconsin: George Banta Publishing Company, 1950.

Kaufman, Burton I. The Korean War: Philadelphia: Temple University Press, 1986.

Koenic, louis W. The Truman Administration. New York: New York University Press, 1956.

Koh, Byung Chul. The Foreign Policy Of North Korea. New York: Frederick A. Praeger, Publishers, 1969.

Leckie, Robert. Conflict The History Of The Korean War: New York: G.P. Putnam's Sons, 1962.

Liu, Suinian and Wu Qungan. China's Socialist Economy An Outline History (19491984). Beijing: Beijing Review, 1986.

MacFarquhar, Roderick. Sino-American Relations, 1949-1971. New York: Praeger Publishers, 1972.

Matray, James Irving. The Reluctant Crusade American Foreign Policy In Korea, 1941-1950. Honolulu: University of Hawaii Press, 1985.

MacDonald, Callum A. Korea The War Before Vietnam. New York: The Free Press, 1986.

McGovern, James. To The Yalu. New York: William Morrow \& Company, Inc., 1972.

McLellan, David S. Dean Acheson The State Department Years. New York: Dodd, Mead \& Company, 1976.

Meisner, Mautice. Mao's China. New York: The Free Press, 1977.

North, Robert C. The Foreign Relations Of China. Massachusetts: Duxbury Press, 
1978

Paige, Glenn D. The Korean Decision. New York: The Free Press, 1968.

Paige, Glenn D. 1950: Tiuman's Decision The United States Enters The Korean War. New York: Chelsea House Publishers, 1970.

Poen, Monte M. Strictly Personal And Confidential. Boston . Toronto: Little, Brown And Company, 1982.

The Public Relations Association of Korea. The Truth Behind The Korean War. Seoul, Korea, 1973.

Prybyla, Jan S. The Chinese Economy. South Carolina: University Of South Carolina Press, 1978.

Rees, David. Korea: The Limited War: New York: MacMillan \& Co Ltd., 1964.

Ridgway, Matthew B. The Korean War. New York: Doubleday \& Company, Inc., 1967.

Rovere, Richard H. et al.. The General And The President And The Future Of American Foreign Policy. New York: Farrar, Straus And Young, 1951.

Schwartz, Benjamin. Chinese Communism And The Rise Of Mao. Massachusetts: Harvard University Press, 1951.

Simmons, robert. The Strained Alliance. New York: A Free Press, 1975.

Smith, Gaddis. Dean Acheson. The american secretaries Of State And Their Diplomacy. New York: Publishers Inc., 1972.

Spurr, Russell. Enter The Dragon. New York: Newmarket Press, 1988.

Stone, I.F. The Hidden History Of The Korean War. New York: Monthly Review Press, 1952.

Stueck, William Whitney, Jr. The Road To Confinntation American Policy Toward China and Korea, 1947-1950. Chapel Hill: The University Of North Carolina Press, 1981.

Sunoo, Harold Hakwon. America's Dilemma In asia: The Case Of South Korea. Chicago: Nelson-Hall, 1979. 
Traverso, Edmund. Korean And The Limits Of Limited War. Menlo Park, California: Addison-Welsey Publishing Company, 1970.

Tully, Andrew. CIA The Inside Story. New York: William Morrow And Company, 1962.

Whiting, Allen S. China Crosses The Yalu. New York: The MacMillan Company, 1960.

Wang, Gungwu. China And The Wortd Since 1949. New York: St. Matin's Press, 1977.

Wu, Aitchen K. China And The Soviet Union. New York: Kenikat Press Inc., 1950.

III. PERIODICALS \& NEWSPAPERS

Beijing Review

China Quarterly

Diplomatic History

Guangming Daily (in Chinese)

Hongqi (CCP party Magazine, in Chinese)

The Joumal Of American-East Asian Relations

Junshi shilin(CCP Military History, in Chinese)

New York Times

People's Daily (in Chinese)

Political Science Quarterly 